\title{
The Potential of Phytochemicals in Oral Cancer Prevention and Therapy: A Review of the Evidence
}

\author{
Tzu-Ying Lee ${ }^{(\mathbb{B}}$ and Yu-Hsin Tseng * ${ }^{(\mathbb{C}}$ \\ Department of Pediatrics, Kaohsiung Medical University Hospital, Kaohsiung Medical University, \\ Kaohsiung 807, Taiwan; myleety@hotmail.com \\ * Correspondence: grapepuff@gmail.com; Tel.: +886-7-3121101 (ext. 6356)
}

Received: 7 July 2020; Accepted: 3 August 2020; Published: 6 August 2020

\begin{abstract}
The etiological factors of oral cancer are complex including drinking alcohol, smoking tobacco, betel quid chewing, human papillomavirus infection, and nutritional deficiencies. Understanding the molecular mechanism of oral cancer is vital. The traditional treatment for patients with oral squamous cell carcinoma (e.g., surgery, radiotherapy, and chemotherapy) and targeted molecular therapy still have numerous shortcomings. In recent years, the use of phytochemical factors to prevent or treat cancer has received increasing attention. These phytochemicals have little or no toxicity against healthy tissues and are thus ideal chemopreventive agents. However, phytochemicals usually have low water solubility, low bioavailability, and insufficient targeting which limit therapeutic use. Numerous studies have investigated the development of phytochemical delivery systems to address these problems. The present article provides an overview of oral cancer including the etiological factors, diagnosis, and traditional therapy. Furthermore, the classification, dietary sources, anticancer bioactivity, delivery system improvements, and molecular mechanisms against oral cancer of phytochemicals are also discussed in this review.
\end{abstract}

Keywords: oral squamous cell carcinoma; oral cancer; phytochemicals

\section{Introduction}

Oral cancer refers to cancers that originate in the mouth. Oral squamous cell carcinoma (OSCC) is the commonest type of oral cancer. It is characterized by aggressive tumors of varying degrees of differentiation that tend to have extensive lymph node metastases at an early stage. Therefore, the overall 5 years survival rate for OSCC was below $50 \%$ in the past few decades [1,2]. Traditional treatments of patients with OSCC (e.g., surgery, radiotherapy, and chemotherapy) and targeted molecular therapy still have numerous shortcomings. Therefore, we aimed to identify methods for prevention and treatment that may alter the outcome of this disease. Phytochemicals are natural biologically active compounds with potential health benefits; they have become a focus in recent years. Phytochemicals have been demonstrated to have anticancer effects, mainly by regulating epigenetics/epigenomics [3]; targeting cancer stem cells (CSCs) [4]; inhibiting cancer metastasis [5]; improving human immunity, antioxidation activity and anti-inflammatory responses [6]; inhibiting cancer cell cycle progression [7]; inhibiting cell signal transduction [8]; promoting cancer cell apoptosis [7]; and eventually, achieve the effect of inhibiting cancer cell proliferation and angiogenesis [9-11]. Several key mechanisms have been explored in leading to cell cycle arrest, proliferation inhibition, and apoptosis induction, such as down-regulation of cell cycle regulators cyclins [12-14] and cyclin dependent kinases [12], PI3K/Akt/mTOR and Erk signaling [15], anti-apoptotic proteins Bcl-2 and Bcl-xL [13], as well as enhancing tumor suppressor p21 [12,13] and p53 [13], pro-apoptotic proteins Bax, caspases and poly (ADP-ribose) polymerase (PARP) $[13,14]$. The antioxidant defense mechanism of phytochemicals enhances specific genes encoding antioxidant proteins through the key transcription factor Nrf2, 
and its downstream antioxidant proteins include heme oxygenase-1, catalase, glutathione peroxidase, quinone oxidoreductase 1 , superoxide dismutase, glutathione S-transferase, and glutamate cysteine ligase [16-18]. Finally, the anti-inflammatory mechanism of phytochemicals is mediated by inhibiting the activity of several pro-inflammatory cytokines, including TNF $\alpha$, IL-1, IL-6, iNOS, COX-2, and nuclear factor- $\mathrm{KB}(\mathrm{NF} \kappa \mathrm{B})$ [19]. In this review, we discuss the potential of selected phytochemicals for the prevention and treatment of oral cancer.

\section{Overview of Oral Cancer: OSCC}

\subsection{Definition of OSCC, Incidence, and Mortality}

Oral cancer, a subgroup of head and neck cancer, is one of the most common malignancies globally. The OSCC accounts for over $90 \%$ of all oral cancers and $38 \%$ of head and neck tumors [20,21], and is defined as a malignant epithelial neoplasm exhibiting squamous differentiation characterized by the formation of keratin or the presence of intercellular bridges [22]. Anatomically, the oral cavity includes several subsites: lips, anterior two-thirds of the oral tongue, floor of the mouth, buccal mucosa, upper and lower gingivae, retromolar trigone, and hard palate [23,24]. The OSCC is usually observed in three major subsites: the tongue, buccal mucosa, and lips [25]. A report by the International Agency for Research on Cancer (IARC) [26] "Global Cancer Statistics 2018" reported that 18.1 million new cancer cases and 9.6 million cancer deaths occurred worldwide in 2018. An estimated 354,864 new cases and 177,384 deaths of men and women of all ages worldwide reported lip and oral cancers [26]. A database provided by a tool that predicts the future cancer incidence and mortality burden worldwide indicated that the number of lips and oral cancers will increase from 354,864 to 545,396 , and the number of deaths will increase from 177,384 to 275,164 from 2018 to 2040 [27].

\subsection{Risk Factors}

\subsubsection{Tobacco Smoking}

The IARC has classified tobacco smoking as a type 1 carcinogen in the oral cavity including smokeless tobacco [28]. Smoking accounts for $75 \%$ of all oral cancer cases [29]. Smokers have a two to five times higher risk of developing oral cancer compared with nonsmokers [30]. Numerous clinical and epidemiological data have indicated that OSCC caused by tobacco smoking may cause epigenetic changes in oral epithelial cells, suppress immune system function, and cause oxidative stress [31]. Tobacco smoke contains at least 70 carcinogens and cancer-promoting substances [32]. Examples of such carcinogens are nicotine, hydrogen cyanide, formaldehyde, heavy metals (e.g., lead, arsenic), ammonia, radioactive elements (e.g., uranium), phenol, benzene, carbon monoxide, nitrosamines, and polycyclic aromatic hydrocarbons $[33,34]$. Among them, tobacco-specific nitrosamines (TSNAs) and polycyclic aromatic hydrocarbons (PAHs) may play critical roles in cancer $[33,35]$. The TSNAs, such as $\mathrm{N}^{\prime}$-nitrosonornicotine (NNN) and 4-(methylnitrosamino)-1-(3-pyridyl)-1-butanone (NNK), are involved in the metabolic activation of NNK and NNN, which induce harmful mutations in oncogenes and tumor suppressor genes by forming covalently bound DNA adducts that are considered an onset of carcinogenesis $[35,36]$. The carcinogen benzo[a]pyrene $(\mathrm{BaP})$ is the most thoroughly studied prototypical PAHs. The BaP is the main component of cigarette smoke. Cytochrome P450 enzymes can metabolize $\mathrm{BaP}$ and activate it into a carcinogenic reactive intermediate or metabolite. The produced substances can bind to DNA and form DNA adducts that interfere with DNA replication [37]. Metabolically activated BaP may cause cytotoxicity, teratogenicity, genotoxicity, immunotoxicity, mutagenesis, and carcinogenesis $[37,38]$.

\subsubsection{Alcohol}

Alcohol consumption has been considered a critical risk factor for the development of oral cancer. Alcohol can cause local changes, including (1) changing the morphology of the oral mucosa and, thus, 
increasing permeability; (2) dissolving the lipid component of the epithelium and, thus, reducing its thickness and causing atrophy; (3) destroying DNA synthesis and repair through the mutagenic and carcinogenic effects of metabolite acetaldehyde and interfering with the enzymes responsible for DNA repair by binding to proteins; and (4) destroying salivary gland function and, thus, causing a reduction in the local carcinogen clearance rate. These changes increase the risk of oral cancer [39-42].

\subsubsection{Betel Quid}

The IARC revealed that betel quid and areca nut are not only psychostimulant and addictive substances but have also been classified as group I carcinogens in humans [43]. The main components of areca nut are betel quid alkaloids and polyphenols which may cause oral and pharynx cancer [44]. Betel quid alkaloids are considered to be the active ingredient of the areca nut, and the arecoline in alkaloids is the main source of toxicity, followed by arecaidine. Arecoline and arecaidine are mutagens that can induce DNA strand breaks, chromosome aberrations, sister chromatid exchange, and micronucleus formation in mammalian cells [45]. Furthermore, arecoline can also form areca nut-specific nitrosamine substances (areca-specific N-nitrosamines) through nitrosation reaction in the oral and digestive tract of the human body, thereby causing abnormal cell proliferation and canceration [46]. The polyphenols contained in areca nut have carcinogenic and anti-carcinogenic effects. For example, some reports indicate that the beneficial effects of polyphenols include antioxidant capacity to prevent damage caused by oxidative stress [47] as well as their biological effects through chromatin remodeling and other epigenetic modifications [48-50]. On the contrary, a series of studies have shown that polyphenols are another potential active carcinogen because they produce ROS (e.g., $\mathrm{HO})$ and further form 8-OH-dG when mixed with lime to form oral environment alkalines $(\mathrm{pH} \geq 9.5)$ which subsequently destroys DNA [44,51,52]. Although lime itself is not mutagenic, the interaction between polyphenols and lime is the main determinant of ROS generation [44]. Furthermore, ROS can attack salivary proteins and oral mucosa, cause changes in the structure of oral mucosa, and assist in the penetration of toxic substances [53].

\subsubsection{Human Papillomavirus}

Currently, over 200 different human papillomavirus (HPV) subtypes have been isolated from humans [54], the most common is the high-risk subtype HPV-16 which is classified by IARC as a cause of oral and pharyngeal tonsil cancers [55]. The less common subtype HPV-18 is also classified as a cause of oral cancer [55]. Evidence indicates that HPV enhances mutagenic effects through the two major virus-encoded oncoproteins E6 and E7. These proteins regulate the cell cycle, apoptosis, and genetic stability signaling pathways by increasing the mutation of tumor suppressor genes $p 53$ and RB1 and the degradation of their products, which may cause lesions in human oral epithelial cells [56-58].

\subsubsection{Nutritional Deficiencies}

Insufficient dietary intake of vegetables and fruits causes nutrient and mineral deficiencies (e.g., carotenoids, antioxidant vitamins, phenols, terpenoids, steroids, indoles, and fibers), which increases the risk of cancer. These foods contain protective bioactive compounds called phytochemicals. A lack of phytochemicals is believed to contribute to the development of oral diseases [59,60].

\subsubsection{Other Factors}

Several studies have demonstrated that the risk of cancer is increased by several other factors such as immune conditions (e.g., congenital defects in the immune system and organ transplant recipients who are administered immunosuppressant drugs), environmental pollutants (e.g., arsenic, chromium and nickel), occupational exposures (e.g., ultraviolet radiation), microorganisms (e.g., bacteria), and genetic diseases (e.g., Fanconi anemia, dyskeratosis congenita, and Bloom syndrome) [61-64]. 


\subsection{Pathological Symptoms}

Clinical manifestations and histopathological features are the main basis of clinical diagnosis, and OSCC originates from precancerous lesions of the internal squamous epithelium of the oral cavity [65]. Common signs include leukoplakia, erythroplakia, submucosal fibrosis, verrucous hyperplasia, lichenoid dysplasia, and chronic ulcers in various parts of the oral cavity [66-68].

\subsubsection{Clinical Manifestations}

The most common clinical precancerous lesions of OSCC are hyperplasia or atrophy following chronic inflammation or carcinogenic stimuli, characterized by leukoplakia, erythroplakia, or erythroleukoplakia [61]. The two main types of leukoplakia are homogeneous leukoplakia (generally smooth, uniformly thin and cracked, with consistent whiteness) and nonhomogeneous leukoplakia (generally variable thickness and different shapes such as fissured, granular, nodular, and even verrucous). Nonhomogeneous leukoplakia carries a higher risk of malignant transformation than homogeneous leukoplakia $[69,70]$. The prevalence of erythroplakia is relatively low; however, it has a higher potential to transform into malignant tumors than leukoplakia $[66,71]$. Histopathologies have demonstrated that $51 \%$ of erythroplakia lesions are invasive SCC, $40 \%$ are carcinoma in situ, and $9 \%$ are mild or moderate dysplasia [72]. The carcinogenic progress of patients with erythroleukoplakia is nearly four times that of patients with homogeneous leukoplakia [73]. The three clinical forms of OSCC may eventually develop into endophytic necrotizing ulcers with irregular and convex induration borders or develop into exophytic clumps. The surface texture may be verrucous, pebbled, or relatively smooth [74]. Furthermore, malignant OSCC changes may also occur in oral submucosal fibrosis and lichen planus. Oral submucous fibrosis is a chronic inflammation that is associated with fibrous lesions of the oral mucosa. The typical clinical features are a burning sensation of the oral mucosa, dry mouth, blanching, stiffening, and ulceration [75]. Oral lichen planus is a chronic inflammatory autoimmune disease mediated by T cells [68]. The clinical manifestations can be divided into papular, plaque-like, atrophic, erosive, linear, reticular, or annular. Among the clinical manifestations, atrophy, ulcer, and erosion have the highest malignant transformation rates [76].

\subsubsection{Histopathological Features}

In 2017, the World Health Organization issued a revised diagnosis and grading of oral epithelial dysplasia based on a combination of eight architectural and eight cytological criteria. The architectural changes include irregular epithelial stratification, loss of polarity of the basal cells, drop-shaped rete ridges, increased number of mitotic figures, abnormal superficial mitosis, premature keratinization in single cells (dyskeratosis), keratin pearls within rete ridges, and loss of epithelial cell cohesion. The cytological changes include abnormal variation in nuclear size, abnormal variation in nuclear shape, abnormal variation in cell size, abnormal variation in cell shape, increased nuclear-cytoplasmic ratio, atypical mitotic figures, increased number and size of nucleoli, and hyperchromasia [77]. Mild dysplasia indicates that the change occurs only in the lower third of the epithelium with a slight polymorphism in the cell or nuclei. Moderate dysplasia exhibits atypical cell hyperplasia that extends to the middle third of the epithelium. Cytological changes are characterized by obvious cell and nuclear abnormalities, accompanied by abnormal mitosis in the basal layers. Architectural changes may cause bulbous rete pegs and are often accompanied by hyperkeratosis. In cases of severe dysplasia, abnormal hyperplasia from the basal layer to the upper third of the epithelium is observed. The cytological changes further include enlarged nuclei, increased nucleoli, significant polymorphism, and mitosis. The architecture usually loses its layering completely. Furthermore, severely abnormal keratinization or even the formation of keratin pearls are observed, and abnormal forms of bulbous rete pegs appear $[65,77,78]$. Carcinomas in situ are the most severe form of epithelial dysplasia, characterized by full-thickness cytological and architectural changes. Microinvasive OSCC is an early malignant tumor that is 
characterized by infiltration of the superficial lamina propria, usually between 0.5 and $2 \mathrm{~mm}$ deep, and is often accompanied by reactive desmoplasia $[79,80]$.

\subsection{Molecular Mechanism}

\subsubsection{Acquisition of Autonomous Proliferative Signaling}

In normal cells, growth factors bind to specific receptors to stimulate cell proliferation and differentiation. However, cancer cells have autonomous, chaotic growth characteristics because of the dysregulation of growth signals [81]. Studies have established that overexpression of epidermal growth factor receptor (EGFR) is significantly associated with an advanced clinical stage of OSCC, a poor survival rate, and an increased risk of recurrence [82]. One of the most frequently altered signaling pathways in squamous cell carcinoma of the head and neck is the EGFR/PI3K/Akt cascade [83,84]. The PI3K pathway is activated when EGFR binds to ligands such as EGF or transforming growth factor- $\alpha$ (TGF- $\alpha$ ), and subsequently promotes phosphatidylinositol 3,4,5-trisphosphate production which initiates Akt activation. Then, Akt activates the NF-kB-mediated antiapoptotic pathway and prevents FOXO-mediated proapoptotic target transcription to promote cell survival $[85,86]$. Furthermore, cyclin D1 regulates the cell cycle from G1 to S. Cyclin D1 overexpression shortens the G1 phase, resulting in abnormal cell proliferation which may eventually promote the occurrence of other genetic damage. Studies have demonstrated that the expression of cyclin D1 is related to the degree of differentiation, lymph node metastasis, and a poor OSCC prognosis $[87,88]$. Ras is one of the most common mutant oncogenes in oral cancer [89,90]. Point mutations in the Ras gene can cause the Ras protein to be permanently activated and induce continuous cell growth. Furthermore, the family of signal transducer and activator of transcription proteins plays a critical role in the development of oral cancer. A study demonstrated that STAT3 promotes OSCC cell migration, invasion, epithelial-mesenchymal transition (EMT), and aerobic glycolysis by inhibiting FOXO1 transcription [91]. Furthermore, a study demonstrated that the expression of phosphorylated STAT3 is related to poor OSCC prognosis [92].

\subsubsection{Evasion of Growth Suppressors}

Several tumor suppressor genes in cancer cells lose their function through mutation, deletion, and methylation [93]. Mutation of the tumor suppressor gene $p 53$ occurs in almost all human tumors. Furthermore, loss of heterozygosity ( $\mathrm{LOH}$ ) at the $p 53$ locus is detected in $47-66 \%$ of head and neck cancers and $35 \%$ of early oral dysplasia $[93,94]$. Another mechanism for promoting p53 degradation is by HPV infection through interaction with the viral regulatory protein E6 to cause ubiquitination and proteolysis of p53 [95]. The tumor suppressor p $16^{\mathrm{INK} 4 \mathrm{~A}}$ is a cell cycle inhibitor. Hypermethylation of the $p 16^{I N K 4 A}$ promoter causes gene silencing which is common in precancerous oral lesions [96].

\subsubsection{Evasion of Apoptosis}

The Bcl-2 gene family and related proteins form the core and main effector of the apoptosis program, especially antiapoptotic proteins $\mathrm{Bcl}-2$ and $\mathrm{Bcl}-\mathrm{xL}$ and proapoptotic proteins Bax and Bak. Coutinho-Camillo et al. [97] demonstrated that Bcl-2 family proteins are involved in OSCC tumorigenesis, differentiation, and metastasis and are associated with poor prognosis.

\subsubsection{Immortalization}

Each replication cycle results in the loss of a small amount of telomeric DNA used as a protective cap. When sufficient loss occurs, cell death is induced. Telomerase prolongs telomeres, allowing cells to replicate indefinitely during immortalization. Telomerase activity is upregulated in both oral epithelial dysplasia and OSCC cases [98]. 


\subsubsection{Induction of Angiogenesis}

Growing tumors require an increased blood supply to obtain sufficient oxygen and nutrients. Therefore, a rich blood vessel network can cause tumors to reach a clinically obvious size and acquire metastatic ability. Vascular endothelial growth factor (VEGF) is an effective stimulator of blood vessel formation, and VEGF expression was determined to increase in all stages of tumor progression. Other critical factors include fibroblast growth factor, platelet-derived growth factor, TGF- $\beta$, TNF- $\alpha$, interleukin 8, and angiopoietins [99]. In OSCC, the microvessel and lymphovessel densities are closely related to tumor size, clinical stage, lymph node metastasis, recurrence rate, and prognosis [100].

\subsubsection{Tissue Invasion and Metastasis}

The critical steps for cancer cell invasion and metastasis are to reduce the adhesion and isolation of tumor cells, the proteolysis of the extracellular matrix, and the migration of tumor cells. The downregulation of E-cadherin reduces the strength of cell adhesion in tissues, resulting in tumor cells easily invading surrounding tissues through the basement membrane. In OSCC, the reduction of E-cadherin is related to invasion, lymph node metastasis, and poor prognosis and can be used as a biomarker to evaluate the progress and prognosis of oral dysplasia and OSCC [101,102]. The degradation of the extracellular matrix and basement membrane requires the participation of matrix metallopeptidases (MMPs). Numerous studies have described the relationship between MMPs and OSCC, which is primarily involved in tumor progression, invasion and metastasis, and poor prognosis [103-105]. Integrins are cell adhesion molecules that mediate the interaction between cells and the extracellular matrix and regulate a variety of functions, including cell motility, invasion, proliferation, and migration [106,107].

\subsection{OSCC Diagnosis}

\subsubsection{Tumor, Node, Metastasis (TNM) Staging System}

The tumor, node, metastasis (TNM) staging system is one tool to classify OSCC, and is based on the assessment of the size of the primary tumor $(\mathrm{T})$, the extent of regional lymph node involvement $(\mathrm{N})$, and the presence of distant metastases (M) [108,109]. In the eighth edition of the AJCC TNM staging manual, the depth of invasion of the primary tumor and the extranodal expansion of lymph node metastases have been included in the $\mathrm{T}$ and $\mathrm{N}$ pathological categories, respectively [110,111]. However, approximately $20-40 \%$ of patients with OSCC have no clinical or imaging evidence of metastasis to lymph nodes; however, histopathological examination of local lymph nodes revealed metastatic growth [112]. Therefore, TNM staging alone is usually insufficient to diagnose the factors critical to OSCC survival. Assessing other characteristics of the tumor, such as the degree of differentiation and the type of invasion, can help in terms of obtaining accurate diagnoses, selecting favorable treatment methods and reliably evaluating the management results.

\subsubsection{Imaging Evaluation}

Because early OSCC usually involves superficial lesions, using medical imaging, such as computed tomography $(\mathrm{CT})$, magnetic resonance imaging (MRI), and positron emission tomography (PET), is crucial for diagnosing and determining the scope of the primary lesion, local lymph node spread, and distant metastasis [61]. Among them, CT can provide a specific diagnosis for the areas of matrix mineralization, lesion density and pattern, and extent of adjacent bone and neurovascular involvement [113]. In addition, MRI is complementary to CT for evaluating head and neck pathology, and provides a clearer contrast resolution than CT for evaluating the extent of local soft-tissue infiltration, medullary bone involvement, and perineural invasion. [114,115]. Furthermore, PET scans can provide physiological and biochemical data related to cell metabolism by using intravenous injection of biological radioactive chemicals that have different biological substance features. These phenomena usually occur before tissue structure changes; thus, PET images may reveal abnormalities 
before CT or MRI [116]. However, the inability to clearly detect positioning is a critical drawback of the PET method. To overcome this problem, anatomically superior imaging methods (e.g., CT and MRI) are used in conjunction with PET (i.e., PET-CT and PET-MRI).

\subsubsection{Biopsy}

Although noninvasive imaging techniques can be used to characterize head and neck tumors, tissue sampling is still the reference standard for the definitive diagnosis of soft-tissue tumors. Exfoliative cytology is a minimally invasive technique. The desquamated or abraded cells can be collected for microscopic examination, and the cytomorphometric changes are assessed as a reliable indicator of dysplasia or neoplastic changes $[117,118]$. Incisional and excisional biopsies are the most commonly used techniques. An incisional biopsy removes a small piece of a suspicious tissue sample from the lesion or mass for diagnosis, whereas excisional biopsy removes the entire tumor and some surrounding normal tissue. Fine needle aspiration biopsy is the use of a thin, hollow needle connected to a syringe to draw a small amount of liquid and very small tissue blocks from a tumor and then observe the presence of tumor cells under a microscope [119]. Liquid biopsy is a noninvasive diagnostic tool that assesses blood, saliva, or other body fluid samples (e.g., urine, seminal plasma, pleural effusion, cerebrospinal fluid, sputum, and feces) [120].

\subsubsection{Biomarkers}

Biomarkers refer to "biomolecules identified in blood, other body fluids, or tissues that indicate normal or abnormal processes, conditions, or diseases, and can be used to observe the body's response to treatments for diseases or conditions" [121]. Studies have investigated the use of nucleic acid and protein changes in saliva, blood, and tissue samples as biomarkers to improve the diagnosis and prognosis of OSCC [122]. Numerous studies have demonstrated that the loss of specific chromosomal regions in known or speculated tumor suppressor genes can be used as an early predictor of the subsequent progression of oral precancerous lesions [123]. Abnormal DNA methylation can silence tumor suppressor gene expression, which is a common phenomenon in malignant tumors and leads to tumorigenesis, aggressiveness, invasiveness, and malignant transformation of oral epithelial dysplasia [124]. MicroRNAs (miRNAs) are functional noncoding RNAs that are involved in posttranscriptional gene regulation; miRNA can regulate the expression of target genes involved in cancer biology by acting as oncogenes or tumor suppressor genes [125]. Therefore, the deregulation of specific miRNAs can engender the initiation and progression of cancer; thus, they are attractive candidates as biomarkers of oral tumors. Furthermore, quantitative proteomics technology has analyzed potential biomarkers for local and systemic diseases, which could help identify specific proteins involved in disease development and quickly diagnose diseases [126].

\subsection{Therapeutic Alternatives}

Numerous treatments are available for OSCC, depending on the size, location, and stage of the tumor and the overall health of the patient. For patients with stage 1 and stage 2 oral cancer without lymph node spread, no clinical or radiological evidence indicates that metastasis, radiotherapy, or surgical resection is the preferred treatment. Patients with stage 3 and stage 4 (advanced) cancer or with high-risk characteristics should increase the combined treatment of postoperative radiation and chemotherapy. However, the treatment effect of these traditional methods is limited. Targeted molecular therapies have been applied to patients with oral cancer to reduce the side effects of nonspecific cell death and, thus, improve survival rates.

\subsubsection{Surgical Resection}

For resectable tumors, surgery is superior to all other therapies, but for surgical resection, sufficient margins for the primary tumor must be available. Failure to obtain a clear surgical margin leads to an increased risk of local recurrence and subsequently a poor prognosis [127]. 


\subsubsection{Radiation Therapy}

The radiotherapy of OSCC can be achieved by using external beam radiotherapy and brachytherapy [128]. External beam radiotherapy employs special instruments (e.g., linear accelerators and betatrons) to generate high-energy radiation (e.g., X-rays) which can destroy cell chromosomes and prevent cell proliferation when focused on the cancer site from the outside, thereby eliminating cancer cells that can divide and grow rapidly. Brachytherapy implants traditionally provide high-dose radiation to limited tissues through the insertion of an iridium-192 needle or iodine- 125 seed, which can retain the surrounding normal tissues $[129,130]$. Radiation therapy is often used in conjunction with surgery or chemotherapy to kill mitotic cells by destroying DNA.

\subsubsection{Chemotherapy}

Chemotherapy can be used to treat cancers that cannot be surgically removed because of size or dispersion. Chemotherapy slows the growth of cancer for as long as possible and helps relieve any symptoms caused by cancer. The most commonly used chemical drugs for oral cancer are cisplatin, carboplatin, 5-fluorouracil, paclitaxel, docetaxel, and hydroxyurea, which can be used alone or in combination with other drugs [131-133].

\subsubsection{Targeted Therapy}

The EGFR antagonist cetuximab monoclonal antibody is the only first-line targeted therapy for OSCC; it was approved by the U.S. Food and Drug Administration (FDA) in 2006. Cetuximab can inhibit the binding of EGF and EGFR, which interferes with the downstream response induced by EGFR activation. Furthermore, cetuximab enhances local tumor control using radiation therapy [134]. However, patients have a high probability of developing drug resistance in the later period of cetuximab which hinders the clinical treatment effect [135].

\subsubsection{Immunotherapy}

Immunotherapy has been developed as an effective cancer treatment, which controls and kills tumor cells by reducing the suppression state of immune cells in the tumor microenvironment and activating the body's immune function. Tumors employ certain immune-checkpoint pathways as the main mechanism of immune resistance, especially against $\mathrm{T}$ cells that target tumor antigens. Programmed cell death-1 (PD-1) is an immune checkpoint on the surface of T cells. When T cells are activated, PD-1 expression is induced. However, when PD-1 binds to its ligand PD-L1 on tumor cells, it can block the PD-1 pathway and suppress the immune response of $\mathrm{T}$ cells, thereby protecting tumor cells from apoptosis caused by autoimmunity [136]. Nivolumab and pembrolizumab are the first two anti-PD-1 mAbs approved by the FDA [137]. All organ systems can be affected by immune-related adverse events of immune-checkpoint inhibitors. In clinical trials, the most commonly reported effects are dermatologic, gastrointestinal, endocrine, respiratory, and hepatic [138].

\section{Overview of Phytochemicals}

Considerable nutritional epidemiological evidence has indicated that regular consumption of fruits and vegetables is linked to a lower risk of cancer [139-142]. Nutritional compounds have a long history of preventing and treating cancer [142]. Numerous reports have indicated that natural foods, including cruciferous vegetables (e.g., cabbage and broccoli), alliums (e.g., garlic and onion), green tea, citrus fruits, soybeans, tomatoes, berries, and ginger have chemopreventive activity [143]. Therefore, preventing and treating cancer using phytochemicals in natural foods has aroused interest in the academic community. Phytochemicals are derived from plants and are a class of molecules with biological activity. Over 10,000 phytochemicals have been identified worldwide [144,145]. Furthermore, genistein (from soybeans and soy products) [146-148], lycopene (such as from tomatoes, red carrots, watermelons, grapefruits, and papayas) [149-151], brassinin (from cruciferous vegetables) [152-154], 
sulforaphane (from asparagus) [155-157], indole-3-carbinol (from broccoli) [158-160], and resveratrol (from grapes, peanuts, peanut butter, red wines) [161-165] are being studied in preclinical or clinical trials for cancer chemoprevention.

\subsection{Classification and Dietary Sources of Phytochemicals}

Phytochemicals can be divided into phenolic compounds, carotenoids, and others. Phenolic compounds contain one (phenolic acids) or more (polyphenols) aromatic rings with attached hydroxyl groups in their structures. Phenolic acid can be classified into hydroxycinnamic acid and hydroxybenzoic acid. Hydroxycinnamic acid is found in cinnamon, coffee, blueberries, kiwis, plums, apples, and cherries. However, hydroxybenzoic acid is found in few consumable plants [49]. Phenolic compounds can be sub-grouped as flavonoids and non-flavonoids [166]. More than 8000 phenolic compounds from plants have been reported, and the half of phenolic compounds is flavonoids presenting as aglycone, glycosides, and methylated derivatives [167]. Flavonoids have several subgroups which include flavonols, flavones, flavanonols, flavanols, flavanones, anthocyanidins, chalcones, and isoflavones [5,168]. Non-flavonoids compounds include phenolic acids, tannins, coumarins, lignans, and stilbens [169]. Among the phenolic compounds, isoflavones, stilbene, coumestan, and lignan have estrogenic activity, so they have been denominated as phytoestrogen $[170,171]$. Among them, coumestans are produced by oxidation of isoflavones-derived pterocarpan; while stilbene and lignan are non-flavonoids group [172]. Phytoestrogens are natural substances that can exert estrogen-like activity because of their chemical structure which is similar to human estrogens (17- $\beta$-estradiol). The commonest phytoestrogens in the diet are isoflavones and lignans, and their main food sources are legumes (especially soybeans) [170]. The affinity of phytoestrogens to estrogen receptors (ERs) is $1 / 100$ to $1 / 10,000$ that of $17-\beta$-estradiol. However, phytoestrogens may reach micromolar concentrations in the bloodstream [170] and, thus, act as both agonists and antagonists. The ER- $\alpha$ and ER- $\beta$ are two distinct ERs. The ER- $\beta$ is a modulator of ER- $\alpha$ activity. Phytoestrogens are defined as selective estrogen receptor modulators and display a higher binding affinity with ER- $\beta$ compared with ER- $\alpha$ [173]. For example, the binding affinity of isoflavone genistein with ER- $\beta$ is 20 to 30 times higher than with ER- $\alpha$ [174], which explains why the administration of phytoestrogens does not produce the classic side effects associated with estrogen administration (cerebrovascular and cardiovascular attacks, higher incidences of endometrial, and breast cancer).

Carotenoids are members of the tetraterpenes family that are responsible for the yellow, orange, or red color of fruits, leaves, and flowers. Carotenoids occur in all organisms capable of photosynthesis, the conversion of solar energy into chemical energy. In plants, carotenoids contribute to photosynthetic machinery and protect plants from photodamage. Nearly 600 carotenoids have been identified in nature. However, only approximately 50 carotenoids are identified in a typical human diet, and approximately 20 carotenoids are present in human blood and tissues [175]. Carotenoids can be divided into provitamin A (e.g., $\alpha$-carotene, $\beta$-carotene, $\gamma$-carotene, and $\beta$-cryptoxanthin) and non-provitamin A compounds [175]. Carotenoids are also classified into two groups, namely, carotenes and xanthophylls, based on their chemical constituents. Carotenoids composed only of hydrocarbons are carotenes, including lycopene, $\alpha$-carotene, $\beta$-carotene, and their oxygenated derivatives are xanthophylls, including $\beta$-citraurin, which contains an aldehyde group; neoxanthin, antheraxanthin, and violaxanthin, which contain epoxide groups; canthaxanthin and echinenone, which contain oxo/keto groups; and $\beta$-cryptoxanthin, zeaxanthin, and lutein, which contain hydroxyl groups [176]. The most common dietary carotenoids are three carotenes ( $\alpha$-carotene, $\beta$-carotene, and lycopene) and three xanthophylls ( $\beta$-cryptoxanthin, lutein, and zeaxanthin) [144]. Dietary carotenoids have been hypothesized to reduce the risk of cancer because of their antioxidant function. Epidemiological studies have demonstrated a correlation between a high carotenoid intake in the diet and a low risk of cancer [177]. The intake of carotenoids potently inhibits cell proliferation, arrests the cell cycle in different phases, and increases apoptosis and antioxidants in cancer cells [175]. $\beta$-Cryptoxanthin (a 
carotenoid) and hesperidin (a flavonoid) display anticancer effects in several tissues. Gavage with pulp or juice containing high levels of $\beta$-cryptoxanthin and hesperidin can inhibit chemically induced rat colon, rat tongue, and mouse lung cancer [178].

In addition to phenolic compounds and carotenoids, phytosterols, nitrogen compounds, and organosulfur compounds are also commonly discussed phytochemicals. Phytosterols are plant derived lipid compounds and usually found in plants or macro fungi, which resemble cholesterol. They can be further classified as sterols, (unsaturated compounds) and stanols (saturated molecules) [169]. Nitrogen compounds are a subclass that contain nitrogen atoms and are classified as alkaloids (a group of plant secondary metabolites, biosynthesized from amino acids) and non-alkaloid derivatives (such as protoalkaloids, pseudoalkaloids, alkamides, lectines, cyanogenic glycosides) [169]. Organic sulfur compounds are a subclass that contain sulfur atoms and mainly found in garlic and cruciferous vegetables [179]. The classification and dietary sources of common phytochemicals are listed in Figure 1.

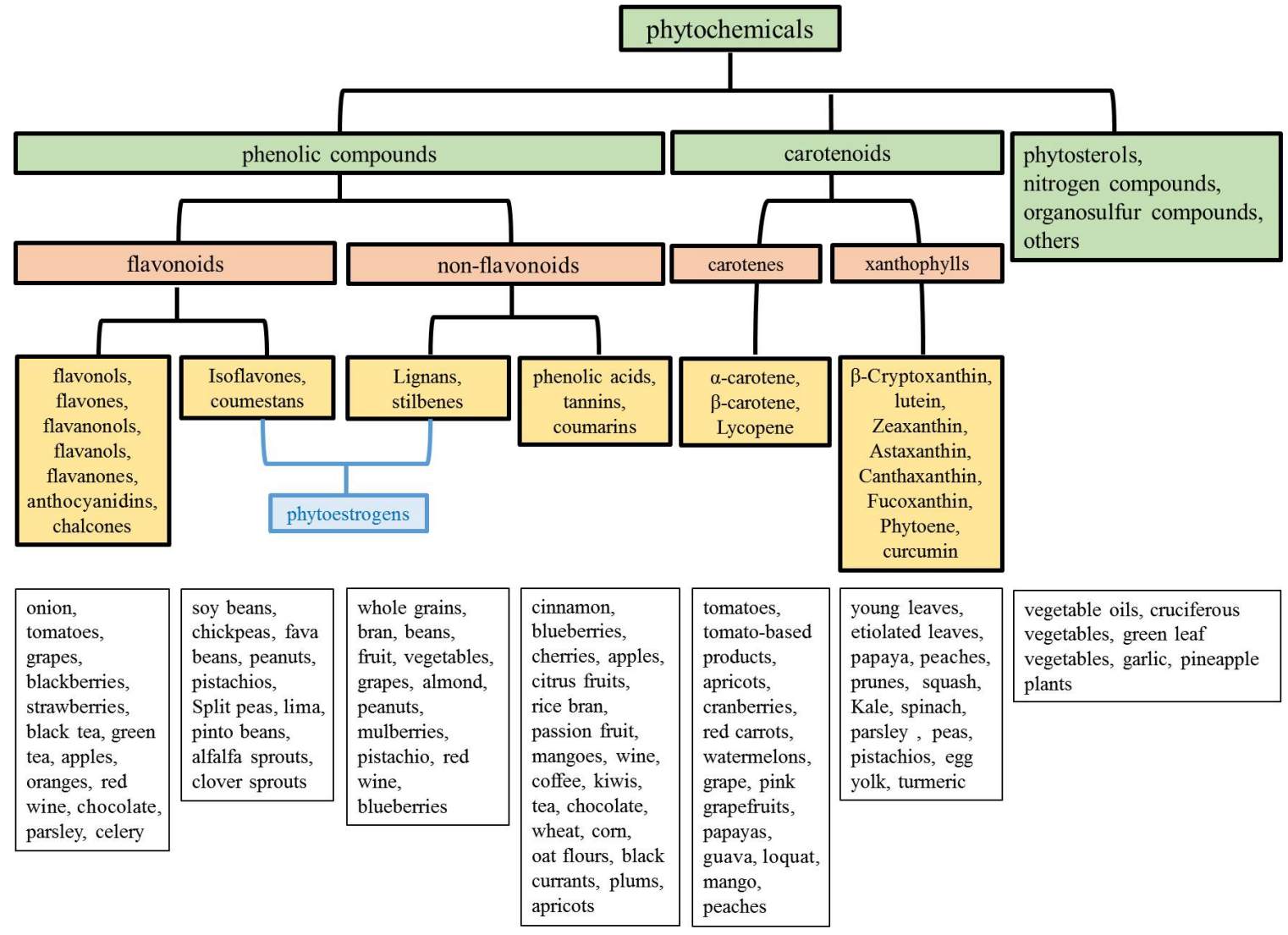

Figure 1. Classification and dietary sources of phytochemicals.

\subsection{Anticancer Bioactivity of Phytochemicals}

Overproduction of oxidants (reactive oxygen species and reactive nitrogen species) in the human body is responsible for the pathogenesis of cancer. Phytochemicals present in fruits, vegetables, and grains have a protective effect against the development of cancers. The protective role of phytochemicals may be associated with their antioxidant activity. Studies have suggested that lifestyle changes could prevent more than two-thirds of human cancers and that dietary factors contribute to approximately 35\% of human cancer mortality [145]. Free radicals are thought to be related to multistage carcinogenic processes. Peroxyl radicals and lipid peroxidation can independently cause DNA mutations, which are essential for the initiation of the carcinogenic process. Antioxidant phytochemicals can regulate the initiation of carcinogenic processes by protecting against DNA damage. For example, green tea polyphenols, silymarin from milk thistle, and proanthocyanidins from grape 
seeds could protect the skin from the adverse effects of UV radiation (e.g., the risk of skin cancers) through four principal mechanisms: reducing UV radiation-induced inflammation, oxidative stress, DNA damage, and immune responses. Furthermore, phytochemicals could inhibit cell proliferation and induce cancer cell death. Quercetin, genistein, and resveratrol exhibited higher induction of quinone reductase. The upregulation of quinone reductase is thought to be a useful biomarker for anticarcinogenesis [145]. Furthermore, genistein displayed anticancer effects on breast cancer by demethylating and reactivating methylation-silenced tumor suppressor genes [180]. Lycopene and $\beta$-carotene could inhibit cell proliferation, arrest the cell cycle, and increase apoptosis of human breast cancer cells [181]. In conclusion, oxidative stress contributes to all phases of tumorigenesis (i.e., initiation, promotion, and progression) either by using a direct mechanism involving DNA damage or indirectly by regulating cell signal transduction. Therefore, the reduction of oxidative stress plays a key role in chemoprevention. Dietary phytochemicals have broad prospects through their antioxidant properties. Metastasis represents a serious complication in cancer treatment. Studies have shown flavonoids have anti-cancer effects by regulating key signaling pathways involved in critical steps of metastatic spread in several in vitro and in vivo models [5,182]. Epigenetic changes could occur in the early stages of carcinogenesis preceding genetic mutations, so epigenetics are considered to be promising targets for early interventions against cancer using epigenetic biologically active substances [3]. Several phytochemicals (e.g., curcumin, quercetin, apigenin, (-)-epigallocatechin-3-gallate (EGCG), genistein, resveratrol, sulforaphane, and diallyl disulfide) exert significant chemopreventive effects by targeting multiple anticancer pathways as well as epigenetic mechanisms $[3,183,184]$. The CSCs are a rare subpopulation of cancer cells with abnormal regulation of self-renewal, proliferation or apoptosis, which lead to cancer progression, invasiveness, metastasis formation, and chemotherapy resistance [4]. In various studies, EGCG [185,186], resveratrol [187,188], genistein [189], curcumin [190,191], sulforaphane [192], and diallyl trisulfide [193] have targeted CSCs to express its anticancer ability [4]. Furthermore, phytochemicals exhibit little or no toxicity to healthy tissue and, thus, could be ideal chemopreventive agents.

\subsection{Bioavailability and Delivery System Improvements of Phytochemicals}

The therapeutic effects of natural compounds are usually limited by low water solubility, low bioavailability, and deficient targeting. In order to solve these problems, several studies have focused on the developments of phytochemical delivery systems (e.g., liposomes, nanoparticles, nanoemulsions, films, adjuvants, micelles, and phospholipid complexes) [194]. These delivery systems would enable flavonoids, resveratrol, celastrol, curcumin, berberine, and camptothecin to avoid drug metabolism, overcome physiological barriers, and achieve delivery at a higher concentration at cancer sites [195]. For example, resveratrol has a circulation half-life of several minutes, and flavonoids quercetin and EGCG usually have low micromolar concentrations in the blood, which can be sufficient for cytoprotective action but are considered insufficient to achieve anticancer effects [195-197]. Different delivery systems for resveratrol have been developed (e.g., the resveratrol encapsulation in lipid nanocarriers or liposomes, emulsions, micelles, insertion into polymeric nanoparticles, solid dispersions, and nanocrystals). These systems can facilitate the rapid absorption of large quantities of resveratrol, which then effectively increases plasma concentrations [198]. Furthermore, nanoencapsulation of polyphenols (EGCG, quercetin, curcumin and resveratrol) could prolong circulation, improve localization, enhance efficacy, and reduce the risk of multidrug resistance [199].

\section{Molecular Mechanisms of Phytochemicals against Oral Cancer}

The continuous increase in cancer cases, the failure of conventional chemotherapies, and the excessive toxicity of chemotherapies demand alternative cancer treatments [200]. Phytochemicals can inhibit or antagonize factors, which are dysregulated in cancer cells and may enhance the effects of conventional therapy or could be developed into a stand-alone therapy [140]. Because of the historical presence of phytochemicals in the human diet, the risk of severe adverse events may be 
lower in therapeutic settings compared with synthetic compounds that are entering the human body for the first time. Phytochemicals may exert their chemopreventive properties by blocking the critical events of tumor initiation and promotion, thereby reversing the premalignant stage. Phytochemicals may also prevent tumorigenesis by inhibiting or slowing tumor progression or promoting cell differentiation. Furthermore, phytochemicals can enhance innate immune surveillance and improve the elimination of transformed cells [201]. In this review, we describe the molecular mechanisms of certain phytochemicals, including black raspberries (BRBs), green tea, EGCG, (-)-epigallocatechin (EGC), (-)-epicatechin-3-gallate (ECG), resveratrol, lycopene, curcumin, garlic, onion, astaxanthin, canthaxanthin, and bromelain for oral cancer chemoprevention and treatment (Table 1).

\subsection{BRBS}

The BRBs are rich in vitamins, minerals, fiber, anthocyanins, phenolic components, and other bioactive components with cancer inhibitory capacities [202], and have been reported to inhibit various cancers including oral cancer [203]. In 2002, in a DMBA-induced hamster cheek pouch model, dietary blackberries were determined to have the potential to inhibit oral cancer formation [204]. The mechanisms associated with the inhibition of oral cancer by BRBs were immediately investigated. In lacI rat oral epithelial cells, the extracts of BRB enhances the removal of DNA damage caused by DBP-diol, a primary metabolite of the tobacco-smoke carcinogen, dibenzo-[a,l]-pyrene (DBP) $[205,206]$. In 4-nitroquinoline 1-oxide (4NQO) F344 rats model of oral cancer, BRBs can inhibit oral carcinogenesis by modulating proinflammatory [207,208], apoptotic [208], glycolytic [203], and AMP-activated protein kinase pathways [203]. The local treatment of BRB gel (0.5 g, four times daily) on oral premalignant lesions (OPLs) for 3 months resulted in considerable reductions in lesion size, histologic grade, and LOH at tumor suppressor gene loci $[203,209,210]$.

\subsection{Green Tea, EGCG, EGC, and ECG}

Green tea contains rich flavonoids and other polyphenolic antioxidants, which protect against cancer. Three major constituents of green tea are EGCG, ECG, and EGC. These compounds induced considerable dose-dependent inhibition of cell growth [211]. Among them, EGCG is the major polyphenol to inhibit growth and interfere with the carcinogenic process of various cancer cell lines [212]. Both observational and intervention studies have indicated that green tea intake has a protective effect on the development of oral-digestive tract cancer. Furthermore, oral supplementation of green tea extract had an inhibitory effect on a precancerous lesion of the oral cavity [213]. Studies have indicated that EGCG inhibits both cell proliferation and migration of oral cancer cells, which is associated with a reduction in the expression of phosphorylated EGFR [212], and EGCG can induce cell apoptosis and cell cycle arrest, modulate transcription factors (NF-KB and AP-1), and reduce cell migration and invasion in OSCC cell lines. In animal models of oral carcinogenesis, tea polyphenols reduced oxidative stress and phase I enzymes (cytochrome b5, cytochrome P450, cytochrome b5 reductase, cytochrome P450 reductase, aryl hydrocarbon hydroxylase, and DT-diaphorase) and induced phase II enzyme (glutathione-S-transferase and UDP glucuronyl transferase) [141]. In a mouse xenograft model, EGCG was efficient in inhibiting phorbol-12-myristate-induced cell invasion, MMP-9 expression, and tumor growth [214]. In clinical trials, tea extract intake reduced lesion size in patients with leukoplakia [215]. Tea extract intake reduced stromal VEGF and cyclin D1 expressions in patients with a high-risk of developing OPLs [216]. Clinical trials have also shown that drinking more than 10 cups of green tea per day reduces the risk and delays the onset of cancer compared to those who drink less than 3 cups per day. In addition, smokers taking green tea extract (2000-2500 mg/day) for 4 weeks reduced the DNA damage of oral keratinocytes [217,218].

\subsection{Curcumin}

Curcumin, a xanthophyll carotenoid, is the primary active constituent of turmeric which is derived from the rhizome (root) of Curcuma longa. Turmeric is one of the components of curry [219]. 
The anticancer effects of curcumin and its underlying mechanisms have been studied in several tumor systems including skin, colon, lung, duodenal, stomach, esophageal, and oral cancer. Curcumin inhibits the invasive ability and EMT by reducing the expression of MMP-2 and MMP-9 and modulating the p53-E-cadherin pathway in SCC-25 cells [220]. Curcumin also inhibits cell proliferation of SCC-9 cells by increasing miR-9 expression and inhibiting Wnt/ $\beta$-catenin signaling [221]. Moreover, curcumin activates $\mathrm{p} 38$, which activates the $\mathrm{C} / \mathrm{EBP} \alpha$ transactivator by interacting with the binding element of the IGFBP-5 promoter in SAS cells [222]. Curcumin can also reduce the tumor burden and tumor incidence in 4NQO-, DMBA-, or MAOMN-induced oral cancer models [223,224]. Local treatment with curcumin provided significant symptomatic relief in patients with external cancerous lesions. A study conducted on 62 patients receiving curcumin treatment reported that $10 \%$ of patients had a reduction in lesion size and pain [225]. Curcumin is considered to be pharmacologically safe. The safety and tolerability of curcumin administered at a high dose of $8 \mathrm{~g} /$ day were apparent in clinical trials [194,226].

\subsection{Garlic and Onion}

Several studies have indicated that increased consumption of allium vegetables, such as garlic and onion, can reduce the risk of cancer [227]. S-allylcysteine (SAC) is a garlic constituent that has been reported to effectively inhibit cell proliferation and EMT in human oral squamous cancer CAL-27 cells [228,229] and a mouse xenograft model [228]. The administration of SAC significantly inhibits the development of DMBA-induced hamster buccal pouch (HBP) carcinogenesis by modulating lipid peroxidation and enhancing antioxidant activities $[230,231]$. Furthermore, the combined administration of tomato and garlic significantly inhibits the development of DMBA-induced HBP carcinogenesis by inducing the apoptotic pathway [232]. Although the clinical evidence for the effective doses of garlic for the prevention and treatment of oral cancer is quite limited, no symptoms of garlic toxicity were reported in the literature. According to the clinical trials, increasing the garlic consumption of $20 \mathrm{~g} /$ day reduced the risk of gastric and colorectal cancer [233]. Onion extract significantly delayed tumor formation in DMBA-induced HBP carcinogenesis [234,235]. Quercetin, a principal flavonoid compound in onions, induced cytotoxic effects and reduced migration and invasion of SAS cells [236]. Doses of quercetin ranged from 250 to $5000 \mathrm{mg} /$ day and were evaluated safely in 30 untreated patients with chronic hepatitis c virus infection. Quercetin displayed safety, well tolerated, and no adverse events or signs of toxicity in all trial participants [237]. In some countries, quercetin is available as a dietary supplement, and the recommended dose is $200-1200 \mathrm{mg} /$ day [238,239].

\subsection{Resveratrol}

Resveratrol (3,4',5-trihydroxy-trans-stilbene) is a phytochemical that is naturally produced by numerous plants such as grapes, peanuts, and mulberries. The anticancer properties of resveratrol have been confirmed in various types of cancer including oral cancer [240]. Resveratrol has been shown to inhibit cell growth and DNA synthesis in SCC-25 cell lines. The combination of resveratrol and quercetin can enhance the inhibitory effect of quercetin on cell growth and DNA synthesis [241]. Resveratrol demonstrated considerable efficacy against the growth and proliferation of FaDu and Cal27 cells by inducing DNA damage and apoptosis. The same effect was observed in FaDu tumor xenografts in athymic nude mice [242]. A substantial body of evidence indicates that proinflammatory mediators are associated with cancer progression, invasion, and metastasis. Resveratrol can inhibit or interfere with the main molecular targets of inflammation (e.g., NF- $k B$ and TGF $\beta$ ), which inhibit the activity of regulatory T (Treg) cells [CD4(+)CD25(+)FoxP3(+)], thereby reducing the risk of cancer $[243,244]$. Resveratrol has been found to be safe and reasonably well-tolerated at up to $5 \mathrm{~g}$ /day single dose or as part of a multiple-day dosing regimen in healthy populations [245,246]. However, choosing the right dose of resveratrol to target a specific disease may be tricky. For example, patients with multiple myeloma taking $5 \mathrm{~g}$ of resveratrol (alone or in combination with brtezomib) per day demonstrated renal toxicity, however, no renal toxicity was observed in patients with type 2 diabetics, mitochondrial encephalomyopathy, lactic acidosis, and stroke-like episodes (MELAS) syndrome [247]. For different indications, well-designed human clinical studies are still needed to determine the optimal dose of resveratrol [246]. 


\subsection{Lycopene}

Lycopene is a fat-soluble carotenoid. The main sources of lycopene in the human diet are tomatoes, tomato-based products, apricots, cranberries, grapes, pink grapefruits, guavas, papayas, peaches, and watermelons. Lycopene has a high singlet oxygen quenching ability. It is a useful food coloring agent because of its strong color and nontoxicity. Furthermore, lycopene plays a multifunctional role in the treatment of oral diseases, such as leukoplakia, oral submucous fibrosis, lichen planus, and OSCC [248]. Studies have evaluated the effects of lycopene in the treatment of oral leukoplakia. The results have demonstrated that patients receiving lycopene had a significant difference in responses compared with a placebo. The observed effect of lycopene indicated that it can be used effectively and safely for the treatment of oral leukoplakia [249]. Lycopene exhibits a strong dose-dependent inhibition of proliferation and promotion of the expression of the gap-junction protein connexin-43in KB1 human oral tumor cells [250]. Furthermore, lycopene administration inhibited oral cancer by modulating lipid peroxidation and enhancing the activities of the enzymes in the glutathione redox cycle in a DMBA-induced oral cancer model [251]. The formulation of lycopene is well tolerated and has minimal side effects. However, the absolute absorption of lycopene does not vary greatly with dose. A significant increase in absolute absorption rate was observed only in the low dose range of 10-30 mg lycopene. One study indicated that there was no significant difference in the amount of lycopene absorbed between men who drank juice containing $120 \mathrm{mg}$ of lycopene and men who drank juice containing $10 \mathrm{mg}$ of lycopene [252]. The results of several independent clinical trial studies have pointed out that lycopene consumption of 10-30 mg/day taken for a period of time can effectively reduce the biomarker levels of cancer in patients with prostate cancer and colorectal cancer [253].

\subsection{Xanthophylls (Astaxanthin and Canthaxanthin)}

Micozzi et al. reported that the concentration of oxygenated carotenoids (xanthophylls) in green leafy vegetables is higher than the $\alpha$-carotene or $\beta$-carotene concentrations (10-20\% of total carotenoids), which indicates that xanthophylls may be chemopreventive. The antitumor effects of some xanthophylls, such as canthaxanthin, fucoxanthin, and phytoene, in skin [254], duodenal [255], or mammary tumors [256] have been also reported in limited animal models and in vitro studies. In a 4 NQO-induced oral cancer model, the chemopreventive effects of astaxanthin and canthaxanthin (xanthophylls) were investigated. The incidences of tumors and precancerous lesions in rats treated with 4-NQO and astaxanthin or canthaxanthin were significantly lower than in rats treated with $4 \mathrm{NQO}$ alone [257]. A clinical study to investigate the antioxidant and anti-inflammatory effects of astaxanthin indicated that the level of C-reactive protein in the blood decreased after taking $2 \mathrm{mg} /$ day of astaxanthin for 8 weeks, indicating that the compound had anti-inflammatory activity [258]. Although many studies have investigated the absolute absorption rate and effective concentration of xanthophylls in animal models, but human clinical trials are rarely implemented. Future studies will need to focus on human clinical trials.

\subsection{Bromelain}

Bromelain is a cysteine protease that is mainly extracted from pineapple plants. The anti-inflammatory and anticancer activities of bromelain are recognized. Bromelain is a complex of thiol endopeptidases and non-protease components including phosphatases, glycosidases, peroxidases, cellulases, glycoproteins, ribonuclease, and carbohydrates. Although this enzyme complex has been widely used in various fields, including medicine, health, food, and cosmetics [259], the complete molecular mechanism of action of bromelain has not been completely identified. However, bromelain gained general acceptability as a phytotherapeutic agent because of its history of safe use and lack of side effects [260]. Bromelain treatment inhibited cell growth and proliferation and induced apoptosis in Ca9-22 and SCC25 human oral squamous carcinoma cell lines through various pathways and G1 cell cycle arrest [261]. Bromelain tends to act as a digestive enzyme and its therapeutic effect may be diminished if taken with food. Therefore, it is recommended to take the bromelain capsule $2 \mathrm{~h}$ after the meals. The effective dose of bromelain is $750-1000 \mathrm{mg} /$ day taken for a period of time [262]. 
Table 1. Main anticancer mechanism regulated by natural phytochemicals in oral cancer.

\begin{tabular}{|c|c|c|c|}
\hline Phytochemicals & Model & Anticancer Mechanism & References \\
\hline \multirow{6}{*}{ BRBs } & \multirow[t]{2}{*}{ cell lines } & $\begin{array}{l}\text { - inhibition of cell proliferation } \\
\text { - inhibition of translation of VEGF } \\
\text { - inhibition of nitric oxide synthase activity }\end{array}$ & \multirow[t]{2}{*}{ [263] } \\
\hline & & - induction of apoptosis and terminal differentiation & \\
\hline & $\begin{array}{l}\text { DBP-induced oral cancer } \\
\text { model }\end{array}$ & $\begin{array}{c}\text { - enhancing removal of the DBP-DNA adducts } \\
\text { - enhancing the methylation of genes while hypomethylated by } \\
\text { DBP: Fgf3, Qrich2, Rmdn2, and Cbarp } \\
\text { - suppression of the methylation of genes while hypermethylated } \\
\text { by DBP: Vamp3, Ppp1r13l,Pkm, and Zfp316 }\end{array}$ & {$[205,264,265]$} \\
\hline & \multirow{2}{*}{$\begin{array}{l}\text { 4NQO-induced oral cancer } \\
\text { model }\end{array}$} & $\begin{array}{c}\text { - suppression of the mRNA expression of pro-inflammatory } \\
\text { biomarkers }(\mathrm{C} x \mathrm{cl} 1, \mathrm{Mif} \text {, and } \mathrm{Nfe} 2 \mathrm{l2})\end{array}$ & \multirow[b]{2}{*}[203,207,208]{} \\
\hline & & $\begin{array}{l}\text { - suppression of the mRNA expression of anti-apoptosis and cell } \\
\text { cycle associated markers (Birc5, Aurka, Ccna1, and Ccna2) } \\
\text { - modulation of glycolysis metabolic pathways }\end{array}$ & \\
\hline & clinical trial & $\begin{array}{c}\text { - suppression of the mRNA expression of pro-inflammatory } \\
\text { biomarkers (NFKB1 and PTGS2) and pro-survival biomarkers } \\
\text { (AURKA, BIRC5, and EGFR) } \\
\text { - suppression of LOH events (INK4a/ARF, p53, and FHIT) } \\
\text { - suppression of genes associated with RNA processing and } \\
\text { growth factor recycling } \\
\text { - inhibition of apoptosis } \\
\text { - suppression of COX-2 expression } \\
\text { - suppression of microvessel density }\end{array}$ & [202,208-210] \\
\hline $\begin{array}{l}\text { Green tea, } \\
\text { EGCG, EGC, } \\
\text { ECG }\end{array}$ & cell lines & $\begin{array}{c}\text { - inhibition of cell proliferation } \\
\text { - inhibition of migration and invasion } \\
\text { - induction of apoptosis and cell cycle arrest } \\
\text { - modulate NF- } \mathrm{KB} \text { and AP-1 }\end{array}$ & {$[141,211]$} \\
\hline \multirow{4}{*}{ Curcumin } & cell lines & $\begin{array}{c}\text { - inhibition of cell proliferation, invasive ability, and EMT } \\
\text { - inhibition of the expression of MMP-2 and MMP-9 } \\
\text { - modulating p53-E-Cadherin and Wnt/ } \beta \text {-catenin pathway } \\
\text { - induction of apoptosis } \\
\text { - up-regulation of C/EBPa and IGFBP-5 } \\
\text { - induction of miR-9 expression }\end{array}$ & {$[222,269]$} \\
\hline & $\begin{array}{l}\text { 4NQO-induced oral cancer } \\
\text { model }\end{array}$ & - inhibition of cell proliferation & [270] \\
\hline & $\begin{array}{l}\text { (1) DMBA-induced oral cancer } \\
\text { model (2) MAOMN-induced } \\
\text { oral mucosal tumors }\end{array}$ & - inhibition of the tumor burden and tumor incidence & {$[223,224]$} \\
\hline & clinical trial & - reduced the lesion size and pain. & [225] \\
\hline \multirow[b]{2}{*}{ Garlic } & cell lines & $\begin{array}{l}\text { - inhibition of cell proliferation } \\
\text { - induction of the expression of E-cadherin } \\
\text { - stabilized the E-cadherin/ } \beta \text {-catenin adherent junction complex }\end{array}$ & [229] \\
\hline & $\begin{array}{l}\text { DMBA-induced oral cancer } \\
\text { model }\end{array}$ & $\begin{array}{l}\text { - modulating lipid peroxidation and enhancing the levels of GSH, } \\
\text { GPx, and GST } \\
\text { - downregulation of Bcl-2 and upregulation of Bax, Bim, P53, } \\
\text { caspases 8, and caspases } 3 \text { (the combined administration of } \\
\text { tomato and garlic) }\end{array}$ & [230-232] \\
\hline
\end{tabular}


Table 1. Cont.

\begin{tabular}{|c|c|c|c|}
\hline Phytochemicals & Model & Anticancer Mechanism & References \\
\hline \multirow[t]{2}{*}{ Onion } & cell lines & $\begin{array}{c}\text { - inhibition of cell proliferation, migration, and invasion } \\
\text { - inhibition of the expression and activity of MMP-2 and MMP-9 } \\
\text { - inhibition of NF- } \mathrm{B} \text { B signaling pathways } \\
\text { - induction of the cytotoxic effects }\end{array}$ & {$[234,236]$} \\
\hline & $\begin{array}{l}\text { DMBA-induced oral cancer } \\
\text { model }\end{array}$ & - delay tumor formation & [235] \\
\hline Resveratrol & a mouse xenograft model & $\begin{array}{l}\text { - inhibition of cell growth and proliferation } \\
\text { - induction of DNA damage and apoptosis }\end{array}$ & [242] \\
\hline Lycopene & cell lines & $\begin{array}{l}\text { - inhibition of cell proliferation } \\
\text { - enhanced gap-junction communication } \\
\text { - induction of } C \times 43 \text { expression }\end{array}$ & {$[250,271]$} \\
\hline $\begin{array}{l}\text { Xanthophylls } \\
\text { (astaxanthin } \\
\text { and } \\
\text { canthaxanthin) }\end{array}$ & $\begin{array}{l}\text { 4NQO-induced oral cancer } \\
\text { model }\end{array}$ & - inhibition of proliferation & [257] \\
\hline Bromelain & cell lines & $\begin{array}{c}\text { - induction of PARP, cleavage products, and lamin A/C } \\
\text { degradation } \\
\text { - induction of the sub-G1 population }\end{array}$ & [261] \\
\hline
\end{tabular}

Akt: AKT serine/threonine kinase 1; AURKA: aurora kinase A; Birc5: baculoviral IAP repeat containing 5; BRBs: black raspberries; Cbarp: CACN subunit beta associated regulatory protein; C/EBPa: CCAAT enhancer binding protein alpha; Ccna1: cyclin A1; Ccna2: cyclin A2; COX-2: cyclooxygenase-2; Cxcl1: C-X-C motif chemokine ligand 1; DBP: dibenzo-[a,1]-pyrene; Erk1/2: extracellular signal-regulated protein kinases 1 and 2; Fgf3: fibroblast growth factor 3; FHIT: fragile histidine triad diadenosine triphosphatase; GPx: glutathione peroxidase; GSH: glutathione; GST: glutathione s-transferase; IGFBP-5: insulin-like growth factor-binding protein-5; IkB: inhibitor of NF-kB; Mif: macrophage migration inhibitory factor; mTOR: mechanistic target of rapamycin kinase; NF- $k \mathrm{~B}$ : nuclear factor-kB; Nfe212: nuclear factor, erythroid 2 like 2; NFKB1:nuclear factor kappa b subunit 1; 4NQO: 4-nitroquinoline 1-oxide; AP-1: activator protein-1; ECG: (-)-epicatechin-3-gallate; EGC: (-)-epigallocatechin; EGCG: (-)-epigallocatechin-3-gallate; EGFR: epidermal growth factor receptor; EMT: epithelial-mesenchymal transition; MAOMN: methyl-(acetoxymethyl)-nitrosamine; MMP: matrix metalloproteinase; p53: tumor protein P53; PARP: poly (ADP-ribose) polymerase; Pkm: pyruvate kinase muscle isozyme; Ppp1r131: protein phosphatase 1 regulatory subunit 13 like; PTGS2: prostaglandin-endoperoxide synthase 2; Qrich2: glutamine rich 2; RB1: retinoblastoma gene; Rmdn2: regulator of microtubule dynamics 2; VAMP3: vesicle associated membrane protein 3; VEGF: vascular endothelial growth factor; Zfp316: zinc finger protein 316.

\section{Conclusions}

Tumors can be treated by radiotherapy or surgery in the early stages. However, most patients are diagnosed in the later stages of the disease. Therapy outcomes in the later stages have not dramatically improved in recent years. Epidemiological evidence indicates that regular consumption of fruits and vegetables is linked to a lower risk of cancer. Studies have also provided evidence that dietary phytochemicals exert anticancer effects by modulating various molecular mechanisms. Natural compounds are often hindered by low water solubility, low bioavailability, and deficient targeting; thus, numerous phytochemical delivery systems have been developed to compensate for these problems. The encapsulation of EGCG in polylactic acid-polyethylene glycol (PLA-PEG) nanoparticles can enhance the pro-apoptotic and anti-angiogenic potential [272]. In the mammary tumorigenesis model, the silastic implants delivery of ellagic acid requires only 130 times less than the diet route $(500 \mathrm{ppm})$ to achieve similar anti-cancer effects [273]. Compared with the original curcumin conjugated with phosphatidylcholine can increase the bioavailability by five times and significantly reduce the expression of MMP-9 and lung metastasis in the xenograft model of mammary gland tumor [274]. Cancer is caused by multiple factors, so the use of systemic delivery approaches to deliver multiple agents identified as additively or synergistically targeting multiple and overlapping pathways may be more effective than the use of a single drug. The feasibility of using multiple implants to deliver multiple different compounds (curcumin, green tea polyphenols, punicalagin, and diindolylmethane) 
to a single animal has also been proven [275]. Therefore, if the target organs for the bioaccumulation of chemopreventive agents are identified and delivery systems are developed to increase stability and half-life, great progress can be made in the field of preclinical chemoprevention. In vitro and in vivo experiments on the combined effects of apigenin, curcumin, genistein, resveratrol, EGCG, and sulforaphane with other polyphenols and anticancer drugs have been investigated, and there are many encouraging results [49]. More human clinical trials are required to confirm the anticancer effects of phytochemical factors, but their anticancer potential should not be underestimated.

Author Contributions: T.-Y.L. and Y.-H.T. wrote and edited the manuscript. All authors have contributed equally to this work and approved the final version. All authors have read and agreed to the published version of the manuscript.

Funding: This study was supported by grants from the Ministry of Science and Technology (MOST108-2635-B-037-005 and 109-2314-B-037-103-MY3) and Kaohsiung Medical University Hospital (KMUH108-8R45).

Conflicts of Interest: The authors have no conflicts of interest to declare.

\section{Abbreviations}

4NQO: 4-nitroquinoline 1-oxide; AP-1: activator protein-1; BaP: benzo[a]pyrene; BRBs: black raspberries; CSCs: cancer stem cells; CT: computed tomography; DBP: dibenzo-[a,1]-pyrene; ECG: (-)-epicatechin-3-gallate; EGC: (-)-epigallocatechin; EGCG: (-)-epigallocatechin-3-gallate; EGFR: epidermal growth factor receptor; EMT: epithelial-mesenchymal transition; ERs: estrogen receptors; HBP: hamster buccal pouch; HPV: human papillomavirus; IARC: International Agency for Research on Cancer; LOH: loss of heterozygosity; MAOMN: methyl-(acetoxymethyl)-nitrosamine; miRNAs: microRNAs; MMPs: matrix metallopeptidases; MRI: magnetic resonance imaging; NF- $\mathrm{kB}$ : nuclear factor- $\mathrm{kB}$; NNK: 4-(methylnitrosamino)-1-(3-pyridyl)-1-butanone; NNN: $\mathrm{N}^{\prime}$-nitrosonornicotine; OPL: oral premalignant lesions; OSCC: oral squamous cell carcinoma; PAHs: polycyclic aromatic hydrocarbons; PET: positron emission tomography; SAC: S-allylcysteine; TGF- $\alpha$ : transforming growth factor- $\alpha$; TSNAs: tobacco-specific nitrosamines; VEGF: vascular endothelial growth factor.

\section{References}

1. Quan, H.; Shan, Z.; Liu, Z.; Liu, S.; Yang, L.; Fang, X.; Li, K.; Wang, B.; Deng, Z.; Hu, Y.; et al. The repertoire of tumor-infiltrating lymphocytes within the microenvironment of oral squamous cell carcinoma reveals immune dysfunction. Cancer Immunol. Immunother. 2020, 69, 465-476. [CrossRef] [PubMed]

2. Mascitti, M.; Orsini, G.; Tosco, V.; Monterubbianesi, R.; Balercia, A.; Putignano, A.; Procaccini, M.; Santarelli, A. An overview on current non-invasive diagnostic devices in oral oncology. Front. Physiol. 2018, 9, 1510. [CrossRef] [PubMed]

3. Li, S.; Kuo, H.D.; Yin, R.; Wu, R.; Liu, X.; Wang, L.; Hudlikar, R.; Peter, R.M.; Kong, A.N. Epigenetics/epigenomics of triterpenoids in cancer prevention and in health. Biochem. Pharmacol. 2020, 175, 113890. [CrossRef] [PubMed]

4. Liskova, A.; Kubatka, P.; Samec, M.; Zubor, P.; Mlyncek, M.; Bielik, T.; Samuel, S.M.; Zulli, A.; Kwon, T.K.; Büsselberg, D. Dietary phytochemicals targeting cancer stem cells. Molecules 2019, 24, 899. [CrossRef]

5. Liskova, A.; Koklesova, L.; Samec, M.; Smejkal, K.; Samuel, S.M.; Varghese, E.; Abotaleb, M.; Biringer, K.; Kudela, E.; Danko, J.; et al. Flavonoids in cancer metastasis. Cancers 2020, 12, 1498. [CrossRef]

6. Chen, C.Y.; Kao, C.L.; Liu, C.M. The cancer prevention, anti-inflammatory and anti-oxidation of bioactive phytochemicals targeting the tlr4 signaling pathway. Int. J. Mol. Sci. 2018, 19, 2729. [CrossRef] [PubMed]

7. Mahbub, A.A.; Le Maitre, C.L.; Haywood-Small, S.L.; Cross, N.A.; Jordan-Mahy, N. Polyphenols act synergistically with doxorubicin and etoposide in leukaemia cell lines. Cell Death Discov. 2015, 1, 15043. [CrossRef] [PubMed]

8. Wang, H.; Khor, T.O.; Shu, L.; Su, Z.Y.; Fuentes, F.; Lee, J.H.; Kong, A.N. Plants vs. cancer: A review on natural phytochemicals in preventing and treating cancers and their druggability. Anti-Cancer Agents Med. Chem. 2012, 12, 1281-1305. [CrossRef] [PubMed]

9. Hosseini, A.; Ghorbani, A. Cancer therapy with phytochemicals: Evidence from clinical studies. Avicenna J. Phytomed. 2015, 5, 84-97. [PubMed]

10. Singh, S.; Sharma, B.; Kanwar, S.S.; Kumar, A. Lead phytochemicals for anticancer drug development. Front. Plant Sci. 2016, 7, 1667. [CrossRef] 
11. Choudhari, A.S.; Mandave, P.C.; Deshpande, M.; Ranjekar, P.; Prakash, O. Phytochemicals in cancer treatment: From preclinical studies to clinical practice. Front. Pharmacol. 2019, 10, 1614. [CrossRef] [PubMed]

12. Sun, J.; Hai Liu, R. Cranberry phytochemical extracts induce cell cycle arrest and apoptosis in human MCF-7 breast cancer cells. Cancer Lett. 2006, 241, 124-134. [CrossRef] [PubMed]

13. Aggarwal, B.B.; Bhardwaj, A.; Aggarwal, R.S.; Seeram, N.P.; Shishodia, S.; Takada, Y. Role of resveratrol in prevention and therapy of cancer: Preclinical and clinical studies. Anticancer Res. 2004, 24, 2783-2840. [PubMed]

14. Lee, D.S.; Lee, M.K.; Kim, J.H. Curcumin induces cell cycle arrest and apoptosis in human osteosarcoma (HOS) cells. Anticancer Res. 2009, 29, 5039-5044. [PubMed]

15. Zhang, L.; Wang, H.; Zhu, J.; Xu, J.; Ding, K. Mollugin induces tumor cell apoptosis and autophagy via the PI3K/AKT/mTOR/p70S6K and ERK signaling pathways. Biochem. Biophys. Res. Commun. 2014, 450, 247-254. [CrossRef]

16. Lee, M.T.; Lin, W.C.; Yu, B.; Lee, T.T. Antioxidant capacity of phytochemicals and their potential effects on oxidative status in animals-A review. Asian Australas. J. Anim. Sci. 2017, 30, 299-308. [CrossRef]

17. Linnewiel, K.; Ernst, H.; Caris-Veyrat, C.; Ben-Dor, A.; Kampf, A.; Salman, H.; Danilenko, M.; Levy, J.; Sharoni, Y. Structure activity relationship of carotenoid derivatives in activation of the electrophile/antioxidant response element transcription system. Free Radic. Biol. Med. 2009, 47, 659-667. [CrossRef]

18. Surh, Y.J.; Kundu, J.K.; Na, H.K. Nrf2 as a master redox switch in turning on the cellular signaling involved in the induction of cytoprotective genes by some chemopreventive phytochemicals. Planta Med. 2008, 74, 1526-1539. [CrossRef]

19. Zhang, L.; Virgous, C.; Si, H. Synergistic anti-inflammatory effects and mechanisms of combined phytochemicals. J. Nutr. Biochem. 2019, 69, 19-30. [CrossRef]

20. Jemal, A.; Bray, F.; Center, M.M.; Ferlay, J.; Ward, E.; Forman, D. Global cancer statistics. CA Cancer J. Clin. 2011, 61, 69-90. [CrossRef]

21. Hema, K.N.; Smitha, T.; Sheethal, H.S.; Mirnalini, S.A. Epigenetics in oral squamous cell carcinoma. J. Oral Maxillofac. Pathol. 2017, 21, 252-259. [CrossRef] [PubMed]

22. Sundaram, S.; Rajendran, A. Shafer's Textbook of Oral Pathology, 7th ed.; Elsevier: Kolkata, India; Chennai, India, 2012.

23. Montero, P.H.; Patel, S.G. Cancer of the oral cavity. Surg. Oncol. Clin. N. Am. 2015, 24, 491-508. [CrossRef] [PubMed]

24. Trotta, B.M.; Pease, C.S.; Rasamny, J.J.; Raghavan, P.; Mukherjee, S. Oral cavity and oropharyngeal squamous cell cancer: Key imaging findings for staging and treatment planning. Radiographics 2011, 31, 339-354. [CrossRef] [PubMed]

25. Pires, F.R.; Ramos, A.B.; Oliveira, J.B.; Tavares, A.S.; Luz, P.S.; Santos, T.C. Oral squamous cell carcinoma: Clinicopathological features from 346 cases from a single oral pathology service during an 8-year period. J. Appl. Oral Sci. 2013, 21, 460-467. [CrossRef] [PubMed]

26. Bray, F.; Ferlay, J.; Soerjomataram, I.; Siegel, R.L.; Torre, L.A.; Jemal, A. Global cancer statistics 2018: GLOBOCAN estimates of incidence and mortality worldwide for 36 cancers in 185 countries. CA Cancer J. Clin. 2018, 68, 394-424. [CrossRef]

27. Ferlay, J.; Ervik, M.; Lam, F.; Colombet, M.; Mery, L.; Piñeros, M.; Znaor, A.; Soerjomataram, I.; Bray, F. Global Cancer Observatory: Cancer Tomorrow. Available online: https://gco.iarc.fr/tomorrow (accessed on 12 March 2020).

28. Warnakulasuriya, S.; Straif, K. Carcinogenicity of smokeless tobacco: Evidence from studies in humans \& experimental animals. Indian J. Med. Res. 2018, 148, 681-686.

29. Chaturvedi, P.; Singh, A.; Chien, C.Y.; Warnakulasuriya, S. Tobacco related oral cancer. BMJ 2019, 365, 12142. [CrossRef]

30. Viswanath, A.; Kerns, T.J.; Sorkin, J.D.; Dwyer, D.M.; Groves, C.; Steinberger, E.K. Self-reported oral cancer screening by smoking status in Maryland: Trends over time. J. Public Health Dent. 2013, 73, 261-270. [CrossRef]

31. Jiang, X.; Wu, J.; Wang, J.; Huang, R. Tobacco and oral squamous cell carcinoma: A review of carcinogenic pathways. Tob. Induc. Dis. 2019, 17, 29. [CrossRef]

32. Centers for Disease Control and Prevention (CDC). Tobacco and Cancer. Available online: https://www.cdc. gov/cancer/tobacco/index.htm (accessed on 24 March 2020). 
33. Moracco, K.E.; Morgan, J.C.; Mendel, J.; Teal, R.; Noar, S.M.; Ribisl, K.M.; Hall, M.G.; Brewer, N.T. "My First Thought was Croutons": Perceptions of Cigarettes and Cigarette Smoke Constituents Among Adult Smokers and Nonsmokers. Nicotine Tob. Res. 2016, 18, 1566-1574. [CrossRef]

34. Engstrom, P.F.; Clapper, M.L.; Schnoll, R.A. Holland-Frei Cancer Medicine: Physiochemical Composition of Tobacco Smoke, 6th ed.; BC Decker: Hamilton, ON, Canada, 2003.

35. Xue, J.; Yang, S.; Seng, S. Mechanisms of Cancer Induction by Tobacco-Specific NNK and NNN. Cancers 2014, 6, 1138-1156. [CrossRef] [PubMed]

36. Hecht, S.S.; Hoffmann, D. Tobacco-specific nitrosamines, an important group of carcinogens in tobacco and tobacco smoke. Carcinogenesis 1988, 9, 875-884. [CrossRef] [PubMed]

37. Conney, A.H. Induction of microsomal enzymes by foreign chemicals and carcinogenesis by polycyclic aromatic hydrocarbons: G. H. A. Clowes Memorial Lecture. Cancer Res. 1982, 42, 4875-4917. [PubMed]

38. Rengarajan, T.; Rajendran, P.; Nandakumar, N.; Lokeshkumar, B.; Rajendran, P.; Nishigaki, I. Exposure to polycyclic aromatic hydrocarbons with special focus on cancer. Asian Pac. J. Trop. Biomed. 2015, 5, 182-189. [CrossRef]

39. Rivera, C. Essentials of oral cancer. Int. J. Clin. Exp. Pathol. 2015, 8, 11884-11894. [PubMed]

40. Reidy, J.T.; McHugh, E.E.; Stassen, L.F. A review of the role of alcohol in the pathogenesis of oral cancer and the link between alcohol-containing mouthrinses and oral cancer. J. Ir. Dent. Assoc. 2011, 57, 200-202. [PubMed]

41. Reidy, J.; McHugh, E.; Stassen, L.F. A review of the relationship between alcohol and oral cancer. Surgeon 2011, 9, 278-283. [CrossRef]

42. Ogden, G.R. Alcohol and mouth cancer. Br. Dent. J. 2018, 225, 880-883. [CrossRef]

43. IARC. Betel-quid and Areca-nut Chewing and Some Areca-nut-derived Nitrosamines. IARC Monogr. Eval. Carcinog. Risks Hum. 2004, 85, 1-334.

44. Chen, P.H.; Mahmood, Q.; Mariottini, G.L.; Chiang, T.A.; Lee, K.W. Adverse health effects of betel quid and the risk of oral and pharyngeal cancers. Biomed. Res. Int. 2017, 2017, 3904098. [CrossRef]

45. Sundqvist, K.; Liu, Y.; Nair, J.; Bartsch, H.; Arvidson, K.; Grafstrom, R.C. Cytotoxic and genotoxic effects of areca nut-related compounds in cultured human buccal epithelial cells. Cancer Res. 1989, 49, 5294-5298. [PubMed]

46. Ernst, H.; Ohshima, H.; Bartsch, H.; Mohr, U.; Reichart, P. Tumorigenicity study in Syrian hamsters fed areca nut together with nitrite. Carcinogenesis 1987, 8, 1843-1845. [CrossRef] [PubMed]

47. Stagos, D. Antioxidant activity of polyphenolic plant extracts. Antioxidants 2019, 9, 19. [CrossRef] [PubMed]

48. Carlos-Reyes, Á.; López-González, J.S.; Meneses-Flores, M.; Gallardo-Rincón, D.; Ruíz-García, E.; Marchat, L.A.; Astudillo-de la Vega, H.; Hernández de la Cruz, O.N.; López-Camarillo, C. Dietary compounds as epigenetic modulating agents in cancer. Front. Genet. 2019, 10, 79. [CrossRef]

49. Arora, I.; Sharma, M.; Tollefsbol, T.O. Combinatorial epigenetics impact of polyphenols and phytochemicals in cancer prevention and therapy. Int. J. Mol. Sci. 2019, 20, 4567. [CrossRef]

50. Russo, G.L.; Vastolo, V.; Ciccarelli, M.; Albano, L.; Macchia, P.E.; Ungaro, P. Dietary polyphenols and chromatin remodeling. Crit. Rev. Food Sci. Nutr. 2017, 57, 2589-2599. [CrossRef]

51. Wu, I.C.; Chen, P.H.; Wang, C.J.; Wu, D.C.; Tsai, S.M.; Chao, M.R.; Chen, B.H.; Lee, H.H.; Lee, C.H.; Ko, Y.C. Quantification of blood betel quid alkaloids and urinary 8-hydroxydeoxyguanosine in humans and their association with betel chewing habits. J. Anal. Toxicol. 2010, 34, 325-331. [CrossRef]

52. Nair, U.; Bartsch, H.; Nair, J. Alert for an epidemic of oral cancer due to use of the betel quid substitutes gutkha and pan masala: A review of agents and causative mechanisms. Mutagenesis 2004, 19, 251-262. [CrossRef]

53. Mhaske, S.; Ragavendra, T.R.; Dangi, C.B.S. Areca nut as a chemical carcinogen in oral squamous cell carcinoma- A review. Biomed. Pharmacol. J. 2009, 2, 437-440.

54. Manini, I.; Montomoli, E. Epidemiology and prevention of Human Papillomavirus. Ann. Ig 2018, 30 (Suppl. S1), 28-32.

55. Cogliano, V.J.; Baan, R.; Straif, K.; Grosse, Y.; Lauby-Secretan, B.; El Ghissassi, F.; Bouvard, V.; Benbrahim-Tallaa, L.; Guha, N.; Freeman, C.; et al. Preventable exposures associated with human cancers. J. Natl. Cancer Inst. 2011, 103, 1827-1839. [CrossRef] [PubMed] 
56. Dalianis, T. Human papillomavirus and oropharyngeal cancer, the epidemics, and significance of additional clinical biomarkers for prediction of response to therapy (Review). Int. J. Oncol. 2014, 44, 1799-1805. [CrossRef] [PubMed]

57. Hallikeri, K.; Burde, K.; Anehosur, V.; Kulkarni, B.B.; Hiremath, S.V. p53 polymorphism and association of human papillomavirus in oral submucous fibrosis and oral squamous cell carcinoma: A case-control study. J. Oral Maxillofac. Pathol. 2019, 23, 97-103. [PubMed]

58. Dai, M.; Clifford, G.M.; le Calvez, F.; Castellsague, X.; Snijders, P.J.; Pawlita, M.; Herrero, R.; Hainaut, P.; Franceschi, S.; Group, I.M.O.C.S. Human papillomavirus type 16 and TP53 mutation in oral cancer: Matched analysis of the IARC multicenter study. Cancer Res. 2004, 64, 468-471. [CrossRef] [PubMed]

59. Pflipsen, M.; Zenchenko, Y. Nutrition for oral health and oral manifestations of poor nutrition and unhealthy habits. Gen. Dent. 2017, 65, 36-43. [PubMed]

60. Grimm, M.; Cetindis, M.; Biegner, T.; Lehman, M.; Munz, A.; Teriete, P.; Reinert, S. Serum vitamin D levels of patients with oral squamous cell carcinoma (OSCC) and expression of vitamin D receptor in oral precancerous lesions and OSCC. Med. Oral Patol. Oral Cir. Bucal 2015, 20, e188-e195. [CrossRef] [PubMed]

61. Chi, A.C.; Day, T.A.; Neville, B.W. Oral cavity and oropharyngeal squamous cell carcinoma-an update. CA Cancer J. Clin. 2015, 65, 401-421. [CrossRef]

62. Porter, S.; Gueiros, L.A.; Leao, J.C.; Fedele, S. Risk factors and etiopathogenesis of potentially premalignant oral epithelial lesions. Oral Surg. Oral Med. Oral Pathol. Oral Radiol. 2018, 125, 603-611. [CrossRef]

63. Agrawal, A.; Shindell, E.; Jordan, F.; Baeva, L.; Pfefer, J.; Godar, D.E. UV radiation increases carcinogenic risks for oral tissues compared to skin. Photochem. Photobiol. 2013, 89, 1193-1198. [CrossRef]

64. Srinivasprasad, V.; Dineshshankar, J.; Sathiyajeeva, J.; Karthikeyan, M.; Sunitha, J.; Ragunathan, R. Liaison between micro-organisms and oral cancer. J. Pharm. Bioallied Sci. 2015, 7 (Suppl. S2), S354-S360. [CrossRef]

65. Speight, P.M. Update on oral epithelial dysplasia and progression to cancer. Head Neck Pathol. 2007, 1, 61-66. [CrossRef] [PubMed]

66. Yardimci, G.; Kutlubay, Z.; Engin, B.; Tuzun, Y. Precancerous lesions of oral mucosa. World J. Clin. Cases 2014, 2, 866-872. [CrossRef] [PubMed]

67. Woo, S.B. Oral epithelial dysplasia and premalignancy. Head Neck Pathol. 2019, 13, 423-439. [CrossRef] [PubMed]

68. Irani, S. Pre-cancerous lesions in the oral and maxillofacial region: A literature review with special focus on etiopathogenesis. Iran J. Pathol. 2016, 11, 303-322. [PubMed]

69. Rhodus, N.L.; Kerr, A.R.; Patel, K. Oral cancer: Leukoplakia, premalignancy, and squamous cell carcinoma. Dent. Clin. N. Am. 2014, 58, 315-340. [CrossRef]

70. Parlatescu, I.; Gheorghe, C.; Coculescu, E.; Tovaru, S. Oral leukoplakia-An update. Maedica 2014, 9, 88-93.

71. Villa, A.; Villa, C.; Abati, S. Oral cancer and oral erythroplakia: An update and implication for clinicians. Aust. Dent. J. 2011, 56, 253-256. [CrossRef]

72. Reichart, P.A.; Philipsen, H.P. Oral erythroplakia-A review. Oral Oncol. 2005, 41, 551-561. [CrossRef]

73. Forastiere, A.; Koch, W.; Trotti, A.; Sidransky, D. Head and neck cancer. N. Engl. J. Med. 2001, 345, 1890-1900. [CrossRef]

74. Kashif, M.; Ishfaq, M.; Nagi, A.H. Expression of prostanoid EP3 receptors in oral squamous epithelium and oral squamous cell carcinoma. Pathol. Res. Int. 2015, 2015, 602929. [CrossRef]

75. Tilakaratne, W.M.; Klinikowski, M.F.; Saku, T.; Peters, T.J.; Warnakulasuriya, S. Oral submucous fibrosis: Review on aetiology and pathogenesis. Oral Oncol. 2006, 42, 561-568. [CrossRef] [PubMed]

76. Canto, A.M.; Muller, H.; Freitas, R.R.; Santos, P.S. Oral lichen planus (OLP): Clinical and complementary diagnosis. An. Bras. Dermatol. 2010, 85, 669-675. [CrossRef] [PubMed]

77. Ranganathan, K.; Kavitha, L. Oral epithelial dysplasia: Classifications and clinical relevance in risk assessment of oral potentially malignant disorders. J. Oral Maxillofac. Pathol. 2019, 23, 19-27. [PubMed]

78. Geetha, K.M.; Leeky, M.; Narayan, T.V.; Sadhana, S.; Saleha, J. Grading of oral epithelial dysplasia: Points to ponder. J. Oral Maxillofac. Pathol. 2015, 19, 198-204. [PubMed]

79. Regmee, P.; Rimal, J.; Maharjan, I.K.; Shrestha, A.; Niroula, D.; Luitel, A.; Chaudhary, S.K. Microinvasion: A clinical dilemma. Kathmandu Univ. Med. J. (KUMJ) 2019, 17, 70-72.

80. Heffner, D.K. Let's make grading of squamous cell carcinomas more meaningful to clinicians (via "Ed's Insight"). Ann. Diagn. Pathol. 2002, 6, 399-403. [CrossRef] 
81. Sasahira, T.; Kirita, T. Hallmarks of cancer-related newly prognostic factors of oral squamous cell carcinoma. Int. J. Mol. Sci. 2018, 19, 2413. [CrossRef]

82. Mehta, A.; Chowdhary, M.; Sinha, R. Immunoscoring of epidermal growth factor receptor expression in recurrent cases of oral squamous cell carcinoma. J. Oral Pathol. Med. 2015, 44, 818-822. [CrossRef]

83. Freudlsperger, C.; Burnett, J.R.; Friedman, J.A.; Kannabiran, V.R.; Chen, Z.; Van Waes, C. EGFR-PI3K-AKT-mTOR signaling in head and neck squamous cell carcinomas: Attractive targets for molecular-oriented therapy. Expert Opin. Ther. Targets 2011, 15, 63-74. [CrossRef]

84. Chang, K.Y.; Tsai, S.Y.; Chen, S.H.; Tsou, H.H.; Yen, C.J.; Liu, K.J.; Fang, H.L.; Wu, H.C.; Chuang, B.F.; Chou, S.W.; et al. Dissecting the EGFR-PI3K-AKT pathway in oral cancer highlights the role of the EGFR variant III and its clinical relevance. J. Biomed. Sci. 2013, 20, 43. [CrossRef]

85. Zhang, X.; Tang, N.; Hadden, T.J.; Rishi, A.K. Akt, FoxO and regulation of apoptosis. Biochim. Biophys. Acta 2011, 1813, 1978-1986. [CrossRef] [PubMed]

86. Li, X.; Guo, S.; Xiong, X.K.; Peng, B.Y.; Huang, J.M.; Chen, M.F.; Wang, F.Y.; Wang, J.N. Combination of quercetin and cisplatin enhances apoptosis in OSCC cells by downregulating xIAP through the NF-kappaB pathway. J. Cancer 2019, 10, 4509-4521. [CrossRef] [PubMed]

87. Saawarn, S.; Astekar, M.; Saawarn, N.; Dhakar, N.; Gomateshwar Sagari, S. Cyclin d1 expression and its correlation with histopathological differentiation in oral squamous cell carcinoma. Sci. World J. 2012, 2012, 978327. [CrossRef] [PubMed]

88. Zhao, Y.; Yu, D.; Li, H.; Nie, P.; Zhu, Y.; Liu, S.; Zhu, M.; Fang, B. Cyclin D1 overexpression is associated with poor clinicopathological outcome and survival in oral squamous cell carcinoma in Asian populations: Insights from a meta-analysis. PLoS ONE 2014, 9, e93210. [CrossRef]

89. Murugan, A.K.; Munirajan, A.K.; Tsuchida, N. Ras oncogenes in oral cancer: The past 20 years. Oral Oncol. 2012, 48, 383-392. [CrossRef]

90. Krishna, A.; Singh, S.; Singh, V.; Kumar, V.; Singh, U.S.; Sankhwar, S.N. Does Harvey-Ras gene expression lead to oral squamous cell carcinoma? A clinicopathological aspect. J. Oral Maxillofac. Pathol. 2018, 22, 65-72.

91. Zheng, M.; Cao, M.X.; Yu, X.H.; Li, L.; Wang, K.; Wang, S.S.; Wang, H.F.; Tang, Y.J.; Tang, Y.L.; Liang, X.H. STAT3 promotes invasion and aerobic glycolysis of human oral squamous cell carcinoma via inhibiting FoxO1. Front. Oncol. 2019, 9, 1175. [CrossRef]

92. Macha, M.A.; Matta, A.; Kaur, J.; Chauhan, S.S.; Thakar, A.; Shukla, N.K.; Gupta, S.D.; Ralhan, R. Prognostic significance of nuclear pSTAT3 in oral cancer. Head Neck 2011, 33, 482-489. [CrossRef]

93. Wang, L.H.; Wu, C.F.; Rajasekaran, N.; Shin, Y.K. Loss of tumor suppressor gene function in human cancer: An overview. Cell Physiol. Biochem. 2018, 51, 2647-2693. [CrossRef]

94. Kashiwazaki, H.; Tonoki, H.; Tada, M.; Chiba, I.; Shindoh, M.; Totsuka, Y.; Iggo, R.; Moriuchi, T. High frequency of p53 mutations in human oral epithelial dysplasia and primary squamous cell carcinoma detected by yeast functional assay. Oncogene 1997, 15, 2667-2674. [CrossRef]

95. Gupta, S.; Gupta, S. Role of human papillomavirus in oral squamous cell carcinoma and oral potentially malignant disorders: A review of the literature. Indian J. Dent. 2015, 6, 91-98. [CrossRef] [PubMed]

96. Agarwal, A.; Kamboj, M.; Shreedhar, B. Expression of p16 in oral leukoplakia and oral squamous cell carcinoma and correlation of its expression with individual atypical features. J. Oral Biol. Craniofac. Res. 2019, 9, 156-160. [CrossRef] [PubMed]

97. Coutinho-Camillo, C.M.; Lourenco, S.V.; Nishimoto, I.N.; Kowalski, L.P.; Soares, F.A. Expression of Bcl-2 family proteins and association with clinicopathological characteristics of oral squamous cell carcinoma. Histopathology 2010, 57, 304-316. [CrossRef]

98. Raghunandan, B.N.; Sanjai, K.; Kumaraswamy, J.; Papaiah, L.; Pandey, B.; Jyothi, B.M. Expression of human telomerase reverse transcriptase protein in oral epithelial dysplasia and oral squamous cell carcinoma: An immunohistochemical study. J. Oral Maxillofac. Pathol. 2016, 20, 96-101. [CrossRef] [PubMed]

99. Ucuzian, A.A.; Gassman, A.A.; East, A.T.; Greisler, H.P. Molecular mediators of angiogenesis. J. Burn Care Res. 2010, 31, 158-175. [CrossRef] [PubMed]

100. Ascani, G.; Balercia, P.; Messi, M.; Lupi, L.; Goteri, G.; Filosa, A.; Stramazzotti, D.; Pieramici, T.; Rubini, C. Angiogenesis in oral squamous cell carcinoma. Acta Otorhinolaryngol. Ital. 2005, 25, 13-17. [PubMed]

101. Gupta, A.; Sharma, S.; Batra, M.; Abidullah, M.; Bhuvinder, S.; Katragadda, P. Role of E-cadherin in progression of oral squamous cell carcinoma: A retrospective immunohistochemical study. J. Contemp. Dent. Pract. 2018, 19, 1105-1110. 
102. Kudo, Y.; Kitajima, S.; Ogawa, I.; Hiraoka, M.; Sargolzaei, S.; Keikhaee, M.R.; Sato, S.; Miyauchi, M.; Takata, T. Invasion and metastasis of oral cancer cells require methylation of E-cadherin and/or degradation of membranous beta-catenin. Clin. Cancer Res. 2004, 10, 5455-5463. [CrossRef]

103. Mishev, G.; Deliverska, E.; Hlushchuk, R.; Velinov, N.; Aebersold, D.; Weinstein, F.; Djonov, V. Prognostic value of matrix metalloproteinases in oral squamous cell carcinoma. Biotechnol. Biotechnol. Equip. 2014, 28, 1138-1149. [CrossRef]

104. Choudhry, N.; Sarmad, S.; Waheed, N.U.A.; Gondal, A.J. Estimation of serum matrix metalloproteinases among patients of oral squamous cell carcinoma. Pak. J. Med. Sci. 2019, 35, 252-256. [CrossRef]

105. Ren, Z.H.; Wu, K.; Yang, R.; Liu, Z.Q.; Cao, W. Differential expression of matrix metalloproteinases and miRNAs in the metastasis of oral squamous cell carcinoma. BMC Oral Health 2020, 20, 24. [CrossRef] [PubMed]

106. Shinohara, M.; Nakamura, S.; Sasaki, M.; Kurahara, S.; Ikebe, T.; Harada, T.; Shirasuna, K. Expression of integrins in squamous cell carcinoma of the oral cavity. Correlations with tumor invasion and metastasis. Am. J. Clin. Pathol. 1999, 111, 75-88. [CrossRef] [PubMed]

107. Hood, J.D.; Cheresh, D.A. Role of integrins in cell invasion and migration. Nat. Rev. Cancer 2002, 2, 91-100. [CrossRef] [PubMed]

108. Brierley, J.; Gospodarowicz, M.; O'Sullivan, B. The principles of cancer staging. Ecancermedicalscience 2016, 10, ed61. [CrossRef] [PubMed]

109. Lydiatt, W.M.; Patel, S.G.; O'Sullivan, B.; Brandwein, M.S.; Ridge, J.A.; Migliacci, J.C.; Loomis, A.M.; Shah, J.P. Head and neck cancers-major changes in the American Joint Committee on cancer eighth edition cancer staging manual. CA Cancer J. Clin. 2017, 67, 122-137. [CrossRef] [PubMed]

110. Kowalski, L.P.; Kohler, H.F. Relevant changes in the AJCC 8th edition staging manual for oral cavity cancer and future implications. Chin. Clin. Oncol. 2019, 8 (Suppl. S1), S18. [CrossRef] [PubMed]

111. Amin, M.B.; Greene, F.L.; Edge, S.B.; Compton, C.C.; Gershenwald, J.E.; Brookland, R.K.; Meyer, L.; Gress, D.M.; Byrd, D.R.; Winchester, D.P. The eighth edition ajcc cancer staging manual: Continuing to build a bridge from a population-based to a more "personalized" approach to cancer staging. CA Cancer J. Clin. 2017, 67, 93-99. [CrossRef]

112. Massano, J.; Regateiro, F.S.; Januario, G.; Ferreira, A. Oral squamous cell carcinoma: Review of prognostic and predictive factors. Oral Surg. Oral Med. Oral Pathol. Oral Radiol. Endod. 2006, 102, 67-76. [CrossRef]

113. Subhawong, T.K.; Fishman, E.K.; Swart, J.E.; Carrino, J.A.; Attar, S.; Fayad, L.M. Soft-tissue masses and masslike conditions: What does CT add to diagnosis and management? Am. J. Roentgenol. 2010, 194, 1559-1567. [CrossRef]

114. Law, C.P.; Chandra, R.V.; Hoang, J.K.; Phal, P.M. Imaging the oral cavity: Key concepts for the radiologist. Br. J. Radiol. 2011, 84, 944-957. [CrossRef]

115. Singh, A.; Thukral, C.L.; Gupta, K.; Sood, A.S.; Singla, H.; Singh, K. Role of MRI in evaluation of malignant lesions of tongue and oral cavity. Pol. J. Radiol. 2017, 82, 92-99. [CrossRef] [PubMed]

116. Ozel, H.E. Use of PET in head and neck cancers. Turk. Arch. Otorhinolaryngol. 2015, 53, 73-76. [CrossRef] [PubMed]

117. Verma, R.; Singh, A.; Badni, M.; Chandra, A.; Gupta, S.; Verma, R. Evaluation of exfoliative cytology in the diagnosis of oral premalignant and malignant lesions: A cytomorphometric analysis. Dent. Res. J. 2015, 12, 83-88.

118. Perez-Sayans, M.; Somoza-Martin, J.M.; Barros-Angueira, F.; Reboiras-Lopez, M.D.; Gandara-Vila, P.; Gandara Rey, J.M.; Garcia-Garcia, A. Exfoliative cytology for diagnosing oral cancer. Biotech. Histochem. 2010, 85, 177-187. [CrossRef] [PubMed]

119. Santos, A.P.; Sugaya, N.N.; Pinto Junior Ddos, S.; Lemos Junior, C.A. Fine needle aspiration biopsy in the oral cavity and head and neck region. Braz. Oral Res. 2011, 25, 186-191. [CrossRef]

120. Peng, M.; Chen, C.; Hulbert, A.; Brock, M.V.; Yu, F. Non-blood circulating tumor DNA detection in cancer. Oncotarget 2017, 8, 69162-69173. [CrossRef]

121. Henry, N.L.; Hayes, D.F. Cancer biomarkers. Mol. Oncol. 2012, 6, 140-146. [CrossRef]

122. Zhong, L.; Liu, Y.; Wang, K.; He, Z.; Gong, Z.; Zhao, Z.; Yang, Y.; Gao, X.; Li, F.; Wu, H.; et al. Biomarkers: Paving stones on the road towards the personalized precision medicine for oral squamous cell carcinoma. BMC Cancer 2018, 18, 911. [CrossRef] 
123. Rao, U.K.M.; Thavarajah, R.; Joshua, E.; Ranganathan, K. Loss of heterozygosity as a marker to predict progression of oral epithelial dysplasia to oral squamous cell carcinoma. J. Oral Maxillofac. Pathol. 2018, 22, 155-160. [CrossRef]

124. Shaw, R. The epigenetics of oral cancer. Int. J. Oral Maxillofac. Surg. 2006, 35, 101-108. [CrossRef]

125. Rapado-González, Ó.; López-López, R.; López-Cedrún, J.L.; Triana-Martínez, G.; Muinelo-Romay, L.; Suárez-Cunqueiro, M.M. Cell-free microRNAs as potential oral cancer biomarkers: From diagnosis to therapy. Cells 2019, 8, 1653. [CrossRef] [PubMed]

126. Amiri-Dashatan, N.; Koushki, M.; Abbaszadeh, H.A.; Rostami-Nejad, M.; Rezaei-Tavirani, M. Proteomics applications in health: Biomarker and drug discovery and food industry. Iran J. Pharm. Res. 2018, 17, 1523-1536. [PubMed]

127. Kamat, M.; Rai, B.D.; Puranik, R.S.; Datar, U.V. A comprehensive review of surgical margin in oral squamous cell carcinoma highlighting the significance of tumor-free surgical margins. J. Cancer Res. Ther. 2019, 15, 449-454. [CrossRef] [PubMed]

128. Huang, S.H.; O'Sullivan, B. Oral cancer: Current role of radiotherapy and chemotherapy. Med. Oral Patol. Oral Cir. Bucal 2013, 18, e233-e240. [CrossRef] [PubMed]

129. Pernot, M.; Hoffstetter, S.; Peiffert, D.; Aletti, P.; Lapeyre, M.; Marchal, C.; Luporsi, E.; Bey, P.; Nancy, V.L. Role of interstitial brachytherapy in oral and oropharyngeal carcinoma: Reflection of a series of 1344 patients treated at the time of initial presentation. Otolaryngol. Head Neck Surg. 1996, 115, 519-526. [CrossRef]

130. Tian, Q.; Zhu, H.H.; Li, H. Interstitial brachytherapy of oral squamous cell carcinoma with ultrasound-guided iodine-125 radioactive seed implantation. Eur. Rev. Med. Pharmacol. Sci. 2018, 22, 1680-1685.

131. Hitt, R.; Lopez-Pousa, A.; Martinez-Trufero, J.; Escrig, V.; Carles, J.; Rizo, A.; Isla, D.; Vega, M.E.; Marti, J.L.; Lobo, F.; et al. Phase III study comparing cisplatin plus fluorouracil to paclitaxel, cisplatin, and fluorouracil induction chemotherapy followed by chemoradiotherapy in locally advanced head and neck cancer. J. Clin. Oncol. 2005, 23, 8636-8645. [CrossRef]

132. Hussain, M.; Gadgeel, S.; Kucuk, O.; Du, W.; Salwen, W.; Ensley, J. Paclitaxel, cisplatin, and 5-fluorouracil for patients with advanced or recurrent squamous cell carcinoma of the head and neck. Cancer 1999, 86, 2364-2369. [CrossRef]

133. Chiang, T.E.; Ho, C.L.; Lin, C.S.; Chen, Y.W. Complete remission in very advanced oral cancer by docetaxel, cisplatin, 5-fluorouracil based induction chemotherapy followed by concurrent chemoradiation. J. Dent. Sci. 2018, 13, 82-84. [CrossRef]

134. Bossi, P.; Platini, F. Radiotherapy plus EGFR inhibitors: Synergistic modalities. Cancers Head Neck 2017, $2,2$. [CrossRef]

135. Ohnishi, Y.; Minamino, Y.; Kakudo, K.; Nozaki, M. Resistance of oral squamous cell carcinoma cells to cetuximab is associated with EGFR insensitivity and enhanced stem cell-like potency. Oncol. Rep. 2014, 32, 780-786. [CrossRef] [PubMed]

136. Hirata-Nozaki, Y.; Ohkuri, T.; Ohara, K.; Kumai, T.; Nagata, M.; Harabuchi, S.; Kosaka, A.; Nagato, T.; Ishibashi, K.; Oikawa, K.; et al. PD-L1-specific helper T-cells exhibit effective antitumor responses: New strategy of cancer immunotherapy targeting PD-L1 in head and neck squamous cell carcinoma. J. Transl. Med. 2019, 17, 207. [CrossRef] [PubMed]

137. Prasad, V.; Kaestner, V. Nivolumab and pembrolizumab: Monoclonal antibodies against programmed cell death-1 (PD-1) that are interchangeable. Semin. Oncol. 2017, 44, 132-135. [CrossRef] [PubMed]

138. Myers, G. Immune-related adverse events of immune checkpoint inhibitors: A brief review. Curr. Oncol. 2018, 25, 342-347. [CrossRef] [PubMed]

139. Zhou, Y.; Zheng, J.; Li, Y.; Xu, D.P.; Li, S.; Chen, Y.M.; Li, H.B. Natural polyphenols for prevention and treatment of cancer. Nutrients 2016, 8,515. [CrossRef]

140. Farrand, L.; Oh, S.W.; Song, Y.S.; Tsang, B.K. Phytochemicals: A multitargeted approach to gynecologic cancer therapy. BioMed Res. Int. 2014, 2014, 890141. [CrossRef]

141. Iriti, M.; Varoni, E.M. Chemopreventive potential of flavonoids in oral squamous cell carcinoma in human studies. Nutrients 2013, 5, 2564-2576. [CrossRef]

142. Gullett, N.P.; Ruhul Amin, A.R.; Bayraktar, S.; Pezzuto, J.M.; Shin, D.M.; Khuri, F.R.; Aggarwal, B.B.; Surh, Y.J.; Kucuk, O. Cancer prevention with natural compounds. Semin. Oncol. 2010, 37, 258-281. [CrossRef]

143. Steinmetz, K.A.; Potter, J.D. Vegetables, fruit, and cancer prevention: A review. J. Am. Diet. Assoc. 1996, 96, 1027-1039. [CrossRef] 
144. Bhavana, S.M.; Lakshmi, C.R. Oral oncoprevention by phytochemicals-A systematic review disclosing the therapeutic dilemma. Adv. Pharm. Bull. 2014, 4 (Suppl. S1), 413-420.

145. Zhang, Y.J.; Gan, R.Y.; Li, S.; Zhou, Y.; Li, A.N.; Xu, D.P.; Li, H.B. Antioxidant phytochemicals for the prevention and treatment of chronic diseases. Molecules 2015, 20, 21138-21156. [CrossRef] [PubMed]

146. Hilakivi-Clarke, L.; Onojafe, I.; Raygada, M.; Cho, E.; Skaar, T.; Russo, I.; Clarke, R. Prepubertal exposure to zearalenone or genistein reduces mammary tumorigenesis. Br. J. Cancer 1999, 80, 1682-1688. [CrossRef] [PubMed]

147. Lakshman, M.; Xu, L.; Ananthanarayanan, V.; Cooper, J.; Takimoto, C.H.; Helenowski, I.; Pelling, J.C.; Bergan, R.C. Dietary genistein inhibits metastasis of human prostate cancer in mice. Cancer Res. 2008, 68, 2024-2032. [CrossRef] [PubMed]

148. Wang, Y.; Raffoul, J.J.; Che, M.; Doerge, D.R.; Joiner, M.C.; Kucuk, O.; Sarkar, F.H.; Hillman, G.G. Prostate cancer treatment is enhanced by genistein in vitro and in vivo in a syngeneic orthotopic tumor model. Radiat. Res. 2006, 166 Pt 1, 73-80. [CrossRef]

149. Kim, D.J.; Takasuka, N.; Nishino, H.; Tsuda, H. Chemoprevention of lung cancer by lycopene. Biofactors 2000, 13, 95-102. [CrossRef]

150. Kucuk, O.; Sarkar, F.H.; Sakr, W.; Djuric, Z.; Pollak, M.N.; Khachik, F.; Li, Y.W.; Banerjee, M.; Grignon, D.; Bertram, J.S.; et al. Phase II randomized clinical trial of lycopene supplementation before radical prostatectomy. Cancer Epidemiol. Biomark. Prev. 2001, 10, 861-868.

151. Seren, S.; Lieberman, R.; Bayraktar, U.D.; Heath, E.; Sahin, K.; Andic, F.; Kucuk, O. Lycopene in cancer prevention and treatment. Am. J. Ther. 2008, 15, 66-81. [CrossRef]

152. Chripkova, M.; Drutovic, D.; Pilatova, M.; Mikes, J.; Budovska, M.; Vaskova, J.; Broggini, M.; Mirossay, L.; Mojzis, J. Brassinin and its derivatives as potential anticancer agents. Toxicol. In Vitro 2014, 28, 909-915. [CrossRef]

153. Kim, S.M.; Oh, E.Y.; Lee, J.H.; Nam, D.; Lee, S.G.; Lee, J.; Kim, S.H.; Shim, B.S.; Ahn, K.S. Brassinin Combined with Capsaicin Enhances Apoptotic and Anti-metastatic Effects in PC-3 Human Prostate Cancer Cells. Phytother. Res. 2015, 29, 1828-1836. [CrossRef]

154. Yang, M.H.; Lee, J.H.; Ko, J.H.; Jung, S.H.; Sethi, G.; Ahn, K.S. Brassinin represses invasive potential of lung carcinoma cells through deactivation of PI3K/Akt/mTOR signaling cascade. Molecules 2019, 24, 1584. [CrossRef]

155. Kamal, M.M.; Akter, S.; Lin, C.N.; Nazzal, S. Sulforaphane as an anticancer molecule: Mechanisms of action, synergistic effects, enhancement of drug safety, and delivery systems. Arch. Pharm. Res. 2020, 43, 371-384. [CrossRef] [PubMed]

156. Jaman, M.S.; Sayeed, M.A. Ellagic acid, sulforaphane, and ursolic acid in the prevention and therapy of breast cancer: Current evidence and future perspectives. Breast Cancer 2018, 25, 517-528. [CrossRef] [PubMed]

157. Dos Santos, P.; Machado, A.R.T.; De Grandis, R.A.; Ribeiro, D.L.; Tuttis, K.; Morselli, M.; Aissa, A.F.; Pellegrini, M.; Antunes, L.M.G. Transcriptome and DNA methylation changes modulated by sulforaphane induce cell cycle arrest, apoptosis, DNA damage, and suppression of proliferation in human liver cancer cells. Food Chem. Toxicol. 2020, 136, 111047. [CrossRef] [PubMed]

158. Wu, Y.; Li, R.W.; Huang, H.; Fletcher, A.; Yu, L.; Pham, Q.; Yu, L.; He, Q.; Wang, T.T.Y. Inhibition of tumor growth by dietary indole-3-carbinol in a prostate cancer xenograft model may be associated with disrupted gut microbial interactions. Nutrients 2019, 11, 467. [CrossRef] [PubMed]

159. Lee, C.M.; Park, S.H.; Nam, M.J. Anticarcinogenic effect of indole-3-carbinol (I3C) on human hepatocellular carcinoma SNU449 cells. Hum Exp. Toxicol. 2019, 38, 136-147. [CrossRef] [PubMed]

160. Katz, E.; Nisani, S.; Chamovitz, D.A. Indole-3-carbinol: A plant hormone combatting cancer. F1000Research 2018, 7, 689. [CrossRef] [PubMed]

161. Hsieh, T.C.; Wu, J.M. Resveratrol suppresses prostate cancer epithelial cell scatter/invasion by targeting inhibition of hepatocyte growth factor (HGF) secretion by prostate stromal cells and upregulation of e-cadherin by prostate cancer epithelial cells. Int. J. Mol. Sci. 2020, 21, 1760. [CrossRef]

162. Ferraz da Costa, D.C.; Pereira Rangel, L.; Martins-Dinis, M.; Ferretti, G.; Ferreira, V.F.; Silva, J.L. Anticancer Potential of Resveratrol, beta-Lapachone and Their Analogues. Molecules 2020, 25, 893. [CrossRef]

163. Carter, L.G.; D'Orazio, J.A.; Pearson, K.J. Resveratrol and cancer: Focus on in vivo evidence. Endocr. Relat. Cancer 2014, 21, R209-R225. [CrossRef] 
164. Yousef, M.; Vlachogiannis, I.A.; Tsiani, E. Effects of resveratrol against lung cancer: In Vitro and in vivo studies. Nutrients 2017, 9, 1231. [CrossRef]

165. Jiang, Z.; Chen, K.; Cheng, L.; Yan, B.; Qian, W.; Cao, J.; Li, J.; Wu, E.; Ma, Q.; Yang, W. Resveratrol and cancer treatment: Updates. Ann. N. Y. Acad. Sci. 2017, 1403, 59-69. [CrossRef] [PubMed]

166. Frond, A.D.; Iuhas, C.I.; Stirbu, I.; Leopold, L.; Socaci, S.; Andreea, S.; Ayvaz, H.; Andreea, S.; Mihai, S.; Diaconeasa, Z.; et al. Phytochemical characterization of five edible purple-reddish vegetables: Anthocyanins, flavonoids, and phenolic acid derivatives. Molecules 2019, 24, 1536. [CrossRef] [PubMed]

167. Tungmunnithum, D.; Thongboonyou, A.; Pholboon, A.; Yangsabai, A. Flavonoids and other phenolic compounds from medicinal plants for pharmaceutical and medical aspects: An overview. Medicines 2018, 5, 93. [CrossRef] [PubMed]

168. Shahidi, F.; Yeo, J. Bioactivities of phenolics by focusing on suppression of chronic diseases: A review. Int. J. Mol. Sci. 2018, 19, 1573. [CrossRef] [PubMed]

169. Costea, T.; Hudiță, A.; Ciolac, O.A.; Gălățeanu, B.; Ginghină, O.; Costache, M.; Ganea, C.; Mocanu, M.M. Chemoprevention of colorectal cancer by dietary compounds. Int. J. Mol. Sci. 2018, 19, 3787. [CrossRef] [PubMed]

170. Viggiani, M.T.; Polimeno, L.; Di Leo, A.; Barone, M. Phytoestrogens: Dietary intake, bioavailability, and protective mechanisms against colorectal neoproliferative lesions. Nutrients 2019, 11, 1709. [CrossRef]

171. Desmawati, D.; Sulastri, D. Phytoestrogens and their health effect. Open Access Maced. J. Med. Sci. 2019, 7, 495-499. [CrossRef]

172. Lecomte, S.; Demay, F.; Ferrière, F.; Pakdel, F. Phytochemicals targeting estrogen receptors: Beneficial rather than adverse effects? Int. J. Mol. Sci. 2017, 18, 1381. [CrossRef]

173. Van de Schans, M.G.; Vincken, J.P.; de Waard, P.; Hamers, A.R.; Bovee, T.F.; Gruppen, H. Glyceollins and dehydroglyceollins isolated from soybean act as SERMs and ER subtype-selective phytoestrogens. J. Steroid Biochem. Mol. Biol. 2016, 156, 53-63. [CrossRef]

174. Kuiper, G.G.; Lemmen, J.G.; Carlsson, B.; Corton, J.C.; Safe, S.H.; van der Saag, P.T.; van der Burg, B.; Gustafsson, J.A. Interaction of estrogenic chemicals and phytoestrogens with estrogen receptor beta. Endocrinology 1998, 139, 4252-4263. [CrossRef]

175. Milani, A.; Basirnejad, M.; Shahbazi, S.; Bolhassani, A. Carotenoids: Biochemistry, pharmacology and treatment. Br. J. Pharmacol. 2017, 174, 1290-1324. [CrossRef] [PubMed]

176. Tan, B.L.; Norhaizan, M.E. Carotenoids: How effective are they to prevent age-related diseases? Molecules 2019, 24, 1801. [CrossRef] [PubMed]

177. Leoncini, E.; Nedovic, D.; Panic, N.; Pastorino, R.; Edefonti, V.; Boccia, S. Carotenoid intake from natural sources and head and neck cancer: A systematic review and meta-analysis of epidemiological studies. Cancer Epidemiol. Biomark. Prev. 2015, 24, 1003-1011. [CrossRef] [PubMed]

178. Tanaka, T.; Tanaka, T.; Tanaka, M.; Kuno, T. Cancer chemoprevention by citrus pulp and juices containing high amounts of $\beta$-cryptoxanthin and hesperidin. J. Biomed. Biotechnol. 2012, 2012, 516981. [CrossRef] [PubMed]

179. Mikaili, P.; Maadirad, S.; Moloudizargari, M.; Aghajanshakeri, S.; Sarahroodi, S. Therapeutic uses and pharmacological properties of garlic, shallot, and their biologically active compounds. Iran J. Basic Med. Sci. 2013, 16, 1031-1048. [PubMed]

180. Xie, Q.; Bai, Q.; Zou, L.Y.; Zhang, Q.Y.; Zhou, Y.; Chang, H.; Yi, L.; Zhu, J.D.; Mi, M.T. Genistein inhibits DNA methylation and increases expression of tumor suppressor genes in human breast cancer cells. Genes Chromosom. Cancer 2014, 53, 422-431. [CrossRef]

181. Gloria, N.F.; Soares, N.; Brand, C.; Oliveira, F.L.; Borojevic, R.; Teodoro, A.J. Lycopene and beta-carotene induce cell-cycle arrest and apoptosis in human breast cancer cell lines. Anticancer Res. 2014, 34, 1377-1386.

182. Chikara, S.; Nagaprashantha, L.D.; Singhal, J.; Horne, D.; Awasthi, S.; Singhal, S.S. Oxidative stress and dietary phytochemicals: Role in cancer chemoprevention and treatment. Cancer Lett. 2018, 413, 122-134. [CrossRef]

183. Thakur, V.S.; Deb, G.; Babcook, M.A.; Gupta, S. Plant phytochemicals as epigenetic modulators: Role in cancer chemoprevention. AAPS J. 2014, 16, 151-163. [CrossRef]

184. Guo, Y.; Su, Z.Y.; Kong, A.N. Current perspectives on epigenetic modifications by dietary chemopreventive and herbal phytochemicals. Curr. Pharmacol. Rep. 2015, 1, 245-257. [CrossRef] 
185. Zhu, J.; Jiang, Y.; Yang, X.; Wang, S.; Xie, C.; Li, X.; Li, Y.; Chen, Y.; Wang, X.; Meng, Y.; et al. Wnt/ $\beta$-catenin pathway mediates (-)-Epigallocatechin-3-gallate (EGCG) inhibition of lung cancer stem cells. Biochem. Biophys. Res. Commun. 2017, 482, 15-21. [CrossRef] [PubMed]

186. Lee, S.H.; Nam, H.J.; Kang, H.J.; Kwon, H.W.; Lim, Y.C. Epigallocatechin-3-gallate attenuates head and neck cancer stem cell traits through suppression of Notch pathway. Eur. J. Cancer 2013, 49, 3210-3218. [CrossRef] [PubMed]

187. Cilibrasi, C.; Riva, G.; Romano, G.; Cadamuro, M.; Bazzoni, R.; Butta, V.; Paoletta, L.; Dalprà, L.; Strazzabosco, M.; Lavitrano, M.; et al. Resveratrol impairs glioma stem cells proliferation and motility by modulating the wnt signaling pathway. PLoS ONE 2017, 12, e0169854. [CrossRef] [PubMed]

188. Peng, L.; Jiang, D. Resveratrol eliminates cancer stem cells of osteosarcoma by STAT3 pathway inhibition. PLoS ONE 2018, 13, e0205918. [CrossRef] [PubMed]

189. Fan, P.; Fan, S.; Wang, H.; Mao, J.; Shi, Y.; Ibrahim, M.M.; Ma, W.; Yu, X.; Hou, Z.; Wang, B.; et al. Genistein decreases the breast cancer stem-like cell population through Hedgehog pathway. Stem Cell Res. Ther. 2013, 4, 146. [CrossRef]

190. Li, Y.; Zhang, T. Targeting cancer stem cells by curcumin and clinical applications. Cancer Lett. 2014, 346, 197-205. [CrossRef]

191. Manikandan, R.; Beulaja, M.; Arulvasu, C.; Sellamuthu, S.; Dinesh, D.; Prabhu, D.; Babu, G.; Vaseeharan, B.; Prabhu, N.M. Synergistic anticancer activity of curcumin and catechin: An in vitro study using human cancer cell lines. Microsc. Res. Tech. 2012, 75, 112-116. [CrossRef]

192. Li, Q.Q.; Xie, Y.K.; Wu, Y.; Li, L.L.; Liu, Y.; Miao, X.B.; Liu, Q.Z.; Yao, K.T.; Xiao, G.H. Sulforaphane inhibits cancer stem-like cell properties and cisplatin resistance through miR-214-mediated downregulation of c-MYC in non-small cell lung cancer. Oncotarget 2017, 8, 12067-12080. [CrossRef]

193. Zhang, Q.; Li, X.T.; Chen, Y.; Chen, J.Q.; Zhu, J.Y.; Meng, Y.; Wang, X.Q.; Li, Y.; Geng, S.S.; Xie, C.F.; et al. $\mathrm{Wnt} / \beta$-catenin signaling mediates the suppressive effects of diallyl trisulfide on colorectal cancer stem cells. Cancer Chemother. Pharmacol. 2018, 81, 969-977. [CrossRef]

194. Mirzaei, H.; Shakeri, A.; Rashidi, B.; Jalili, A.; Banikazemi, Z.; Sahebkar, A. Phytosomal curcumin: A review of pharmacokinetic, experimental and clinical studies. Biomed. Pharmacother. 2017, 85, 102-112. [CrossRef]

195. Lagoa, R.; Silva, J.; Rodrigues, J.R.; Bishayee, A. Advances in phytochemical delivery systems for improved anticancer activity. Biotechnol. Adv. 2020, 38, 107382. [CrossRef] [PubMed]

196. Jung, K.H.; Lee, J.H.; Park, J.W.; Quach, C.H.T.; Moon, S.H.; Cho, Y.S.; Lee, K.H. Resveratrol-loaded polymeric nanoparticles suppress glucose metabolism and tumor growth in vitro and in vivo. Int. J. Pharm. 2015, 478, 251-257. [CrossRef] [PubMed]

197. Lagoa, R.; Samhan-Arias, A.K.; Gutierrez-Merino, C. Correlation between the potency of flavonoids for cytochrome c reduction and inhibition of cardiolipin-induced peroxidase activity. Biofactors 2017, 43, 451-468. [CrossRef] [PubMed]

198. Chimento, A.; De Amicis, F.; Sirianni, R.; Sinicropi, M.S.; Puoci, F.; Casaburi, I.; Saturnino, C.; Pezzi, V. Progress to improve oral bioavailability and beneficial effects of resveratrol. Int. J. Mol. Sci. 2019, 20, 1381. [CrossRef]

199. Tabrez, S.; Jabir, N.R.; Adhami, V.M.; Khan, M.I.; Moulay, M.; Kamal, M.A.; Mukhtar, H. Nanoencapsulated dietary polyphenols for cancer prevention and treatment: Successes and challenges. Nanomedicine 2020, 15, 1147-1162. [CrossRef]

200. Ranjan, A.; Ramachandran, S.; Gupta, N.; Kaushik, I.; Wright, S.; Srivastava, S.; Das, H.; Srivastava, S.; Prasad, S.; Srivastava, S.K. Role of Phytochemicals in Cancer Prevention. Int. J. Mol. Sci. 2019, 20, 4981. [CrossRef]

201. Kotecha, R.; Takami, A.; Espinoza, J.L. Dietary phytochemicals and cancer chemoprevention: A review of the clinical evidence. Oncotarget 2016, 7, 52517-52529. [CrossRef]

202. Kresty, L.A.; Mallery, S.R.; Stoner, G.D. Black raspberries in cancer clinical trials: Past, present and future. J. Berry Res. 2016, 6, 251-261. [CrossRef]

203. Knobloch, T.J.; Ryan, N.M.; Bruschweiler-Li, L.; Wang, C.; Bernier, M.C.; Somogyi, A.; Yan, P.S.; Cooperstone, J.L.; Mo, X.; Bruschweiler, R.P.; et al. Metabolic regulation of glycolysis and amp activated protein kinase pathways during black raspberry-mediated oral cancer chemoprevention. Metabolites 2019, 9 , 140. [CrossRef] 
204. Casto, B.C.; Kresty, L.A.; Kraly, C.L.; Pearl, D.K.; Knobloch, T.J.; Schut, H.A.; Stoner, G.D.; Mallery, S.R.; Weghorst, C.M. Chemoprevention of oral cancer by black raspberries. Anticancer Res. 2002, 22, 4005-4015.

205. Guttenplan, J.B.; Chen, K.M.; Sun, Y.W.; Lajara, B.; Shalaby, N.A.E.; Kosinska, W.; Benitez, G.; Gowda, K.; Amin, S.; Stoner, G.; et al. Effects of black raspberry extract and berry compounds on repair of dna damage and mutagenesis induced by chemical and physical agents in human oral leukoplakia and rat oral fibroblasts. Chem. Res. Toxicol. 2017, 30, 2159-2164. [CrossRef] [PubMed]

206. Guttenplan, J.B.; Chen, K.M.; Sun, Y.W.; Kosinska, W.; Zhou, Y.; Kim, S.A.; Sung, Y.; Gowda, K.; Amin, S.; Stoner, G.D.; et al. Effects of black raspberry extract and protocatechuic acid on carcinogen-dna adducts and mutagenesis, and oxidative stress in rat and human oral cells. Cancer Prev. Res. 2016, 9, 704-712. [CrossRef] [PubMed]

207. Oghumu, S.; Casto, B.C.; Ahn-Jarvis, J.; Weghorst, L.C.; Maloney, J.; Geuy, P.; Horvath, K.Z.; Bollinger, C.E.; Warner, B.M.; Summersgill, K.F.; et al. Inhibition of pro-inflammatory and anti-apoptotic biomarkers during experimental oral cancer chemoprevention by dietary black raspberries. Front. Immunol. 2017, 8, 1325. [CrossRef] [PubMed]

208. Knobloch, T.J.; Uhrig, L.K.; Pearl, D.K.; Casto, B.C.; Warner, B.M.; Clinton, S.K.; Sardo-Molmenti, C.L.; Ferguson, J.M.; Daly, B.T.; Riedl, K.; et al. Suppression of proinflammatory and prosurvival biomarkers in oral cancer patients consuming a black raspberry phytochemical-rich troche. Cancer Prev. Res. 2016, 9, 159-171. [CrossRef] [PubMed]

209. Shumway, B.S.; Kresty, L.A.; Larsen, P.E.; Zwick, J.C.; Lu, B.; Fields, H.W.; Mumper, R.J.; Stoner, G.D.; Mallery, S.R. Effects of a topically applied bioadhesive berry gel on loss of heterozygosity indices in premalignant oral lesions. Clin. Cancer Res. 2008, 14, 2421-2430. [CrossRef]

210. Mallery, S.R.; Tong, M.; Shumway, B.S.; Curran, A.E.; Larsen, P.E.; Ness, G.M.; Kennedy, K.S.; Blakey, G.H.; Kushner, G.M.; Vickers, A.M.; et al. Topical application of a mucoadhesive freeze-dried black raspberry gel induces clinical and histologic regression and reduces loss of heterozygosity events in premalignant oral intraepithelial lesions: Results from a multicentered, placebo-controlled clinical trial. Clin. Cancer Res. 2014, 20, 1910-1924.

211. Elattar, T.M.; Virji, A.S. Effect of tea polyphenols on growth of oral squamous carcinoma cells in vitro. Anticancer Res. 2000, 20, 3459-3465.

212. Belobrov, S.; Seers, C.; Reynolds, E.; Cirillo, N.; McCullough, M. Functional and molecular effects of a green tea constituent on oral cancer cells. J. Oral Pathol. Med. 2019, 48, 604-610. [CrossRef]

213. Yuan, J.M. Cancer prevention by green tea: Evidence from epidemiologic studies. Am. J. Clin. Nutr. 2013, 98 (Suppl. 6), 1676s-1681s. [CrossRef]

214. Chen, P.N.; Chu, S.C.; Kuo, W.H.; Chou, M.Y.; Lin, J.K.; Hsieh, Y.S. Epigallocatechin-3 gallate inhibits invasion, epithelial-mesenchymal transition, and tumor growth in oral cancer cells. J. Agric. Food Chem. 2011, 59, 3836-3844. [CrossRef]

215. Li, N.; Sun, Z.; Han, C.; Chen, J. The chemopreventive effects of tea on human oral precancerous mucosa lesions. Proc. Soc. Exp. Biol. Med. Soc. Exper. Biol. Med. 1999, 220, 218-224. [CrossRef]

216. Tsao, A.S.; Liu, D.; Martin, J.; Tang, X.M.; Lee, J.J.; El-Naggar, A.K.; Wistuba, I.; Culotta, K.S.; Mao, L.; Gillenwater, A.; et al. Phase II randomized, placebo-controlled trial of green tea extract in patients with high-risk oral premalignant lesions. Cancer Prev. Res. 2009, 2, 931-941. [CrossRef] [PubMed]

217. Yoshimura, H.; Yoshida, H.; Matsuda, S.; Ryoke, T.; Ohta, K.; Ohmori, M.; Yamamoto, S.; Kiyoshima, T.; Kobayashi, M.; Sano, K. The therapeutic potential of epigallocatechin-3-gallate against human oral squamous cell carcinoma through inhibition of cell proliferation and induction of apoptosis: In vitro and in vivo murine xenograft study. Mol. Med. Rep. 2019, 20, 1139-1148. [CrossRef] [PubMed]

218. Imai, K.; Suga, K.; Nakachi, K. Cancer-preventive effects of drinking green tea among a Japanese population. Prev. Med. 1997, 26, 769-775. [CrossRef] [PubMed]

219. Cheng, A.L.; Hsu, C.H.; Lin, J.K.; Hsu, M.M.; Ho, Y.F.; Shen, T.S.; Ko, J.Y.; Lin, J.T.; Lin, B.R.; Ming-Shiang, W.; et al. Phase I clinical trial of curcumin, a chemopreventive agent, in patients with high-risk or pre-malignant lesions. Anticancer Res. 2001, 21, 2895-2900. [PubMed]

220. Lee, A.Y.; Fan, C.C.; Chen, Y.A.; Cheng, C.W.; Sung, Y.J.; Hsu, C.P.; Kao, T.Y. Curcumin inhibits invasiveness and epithelial-mesenchymal transition in oral squamous cell carcinoma through reducing matrix metalloproteinase 2, 9 and modulating p53-e-cadherin pathway. Integr. Cancer Ther. 2015, 14, 484-490. [CrossRef] [PubMed] 
221. Xiao, C.; Wang, L.; Zhu, L.; Zhang, C.; Zhou, J. Curcumin inhibits oral squamous cell carcinoma SCC-9 cells proliferation by regulating miR-9 expression. Biochem. Biophys. Res. Commun. 2014, 454, 576-580. [CrossRef]

222. Chang, K.W.; Hung, P.S.; Lin, I.Y.; Hou, C.P.; Chen, L.K.; Tsai, Y.M.; Lin, S.C. Curcumin upregulates insulin-like growth factor binding protein-5 (IGFBP-5) and C/EBPalpha during oral cancer suppression. Int. J. Cancer 2010, 127, 9-20. [CrossRef]

223. Li, N.; Chen, X.; Liao, J.; Yang, G.; Wang, S.; Josephson, Y.; Han, C.; Chen, J.; Huang, M.T.; Yang, C.S. Inhibition of 7,12-dimethylbenz[a]anthracene (DMBA)-induced oral carcinogenesis in hamsters by tea and curcumin. Carcinogenesis 2002, 23, 1307-1313. [CrossRef]

224. Azuine, M.A.; Bhide, S.V. Adjuvant chemoprevention of experimental cancer: Catechin and dietary turmeric in forestomach and oral cancer models. J. Ethnopharmacol. 1994, 44, 211-217. [CrossRef]

225. Kuttan, R.; Sudheeran, P.C.; Josph, C.D. Turmeric and curcumin as topical agents in cancer therapy. Tumori 1987, 73, 29-31. [CrossRef] [PubMed]

226. Gupta, S.C.; Patchva, S.; Aggarwal, B.B. Therapeutic roles of curcumin: Lessons learned from clinical trials. AAPS J. 2013, 15, 195-218. [CrossRef] [PubMed]

227. Galeone, C.; Pelucchi, C.; Levi, F.; Negri, E.; Franceschi, S.; Talamini, R.; Giacosa, A.; La Vecchia, C. Onion and garlic use and human cancer. Am. J. Clin. Nutr. 2006, 84, 1027-1032. [CrossRef] [PubMed]

228. Pai, M.H.; Kuo, Y.H.; Chiang, E.P.; Tang, F.Y. S-Allylcysteine inhibits tumour progression and the epithelial-mesenchymal transition in a mouse xenograft model of oral cancer. Br. J. Nutr. 2012, 108, 28-38. [CrossRef]

229. Tang, F.Y.; Chiang, E.P.; Chung, J.G.; Lee, H.Z.; Hsu, C.Y. S-allylcysteine modulates the expression of E-cadherin and inhibits the malignant progression of human oral cancer. J. Nutr. Biochem. 2009, 20, 1013-1020. [CrossRef]

230. Balasenthil, S.; Nagini, S. Inhibition of 7,12-dimethylbenz[a]anthracene-induced hamster buccal pouch carcinogenesis by S-allylcysteine. Oral Oncol. 2000, 36, 382-386. [CrossRef]

231. Balasenthil, S.; Ramachandran, C.R.; Nagini, S. S-allylcysteine, a garlic constituent, inhibits 7,12-dimethylbenz[a]anthracene-induced hamster buccal pouch carcinogenesis. Nutr. Cancer 2001, 40, 165-172. [CrossRef]

232. Bhuvaneswari, V.; Rao, K.S.; Nagini, S. Altered expression of anti and proapoptotic proteins during chemoprevention of hamster buccal pouch carcinogenesis by tomato and garlic combination. Clin. Chim. Acta 2004, 350, 65-72. [CrossRef]

233. Raghu, R.; Lu, K.H.; Sheen, L.Y. Recent Research Progress on Garlic (dà suàn) as a Potential Anticarcinogenic Agent Against Major Digestive Cancers. J. Tradit. Complement. Med. 2012, 2, 192-201. [CrossRef]

234. Niukian, K.; Schwartz, J.; Shklar, G. In vitro inhibitory effect of onion extract on hamster buccal pouch carcinogenesis. Nutr. Cancer 1987, 10, 137-144. [CrossRef]

235. Niukian, K.; Schwartz, J.; Shklar, G. Effects of onion extract on the development of hamster buccal pouch carcinomas as expressed in tumor burden. Nutr. Cancer 1987, 9, 171-176. [CrossRef] [PubMed]

236. Lai, W.W.; Hsu, S.C.; Chueh, F.S.; Chen, Y.Y.; Yang, J.S.; Lin, J.P.; Lien, J.C.; Tsai, C.H.; Chung, J.G. Quercetin inhibits migration and invasion of SAS human oral cancer cells through inhibition of NF- $\mathrm{kB}$ and matrix metalloproteinase-2/-9 signaling pathways. Anticancer Res. 2013, 33, 1941-1950. [PubMed]

237. Lu, N.T.; Crespi, C.M.; Liu, N.M.; Vu, J.Q.; Ahmadieh, Y.; Wu, S.; Lin, S.; McClune, A.; Durazo, F.; Saab, S.; et al. A phase i dose escalation study demonstrates quercetin safety and explores potential for bioflavonoid Antivirals in patients with chronic hepatitis c. Phytother Res. 2016, 30, 160-168. [CrossRef] [PubMed]

238. Harwood, M.; Danielewska-Nikiel, B.; Borzelleca, J.F.; Flamm, G.W.; Williams, G.M.; Lines, T.C. A critical review of the data related to the safety of quercetin and lack of evidence of in vivo toxicity, including lack of genotoxic/carcinogenic properties. Food Chem. Toxicol. 2007, 45, 2179-2205. [CrossRef] [PubMed]

239. Burak, C.; Brüll, V.; Langguth, P.; Zimmermann, B.F.; Stoffel-Wagner, B.; Sausen, U.; Stehle, P.; Wolffram, S.; Egert, S. Higher plasma quercetin levels following oral administration of an onion skin extract compared with pure quercetin dihydrate in humans. Eur. J. Nutr. 2017, 56, 343-353. [CrossRef] [PubMed]

240. Zlotogorski, A.; Dayan, A.; Dayan, D.; Chaushu, G.; Salo, T.; Vered, M. Nutraceuticals as new treatment approaches for oral cancer: II. Green tea extracts and resveratrol. Oral Oncol. 2013, 49, 502-506. [CrossRef] [PubMed]

241. ElAttar, T.M.; Virji, A.S. Modulating effect of resveratrol and quercetin on oral cancer cell growth and proliferation. Anticancer Drugs 1999, 10, 187-193. [CrossRef] [PubMed] 
242. Tyagi, A.; Gu, M.; Takahata, T.; Frederick, B.; Agarwal, C.; Siriwardana, S.; Agarwal, R.; Sclafani, R.A. Resveratrol selectively induces DNA Damage, independent of Smad4 expression, in its efficacy against human head and neck squamous cell carcinoma. Clin. Cancer Res. 2011, 17, 5402-5411. [CrossRef]

243. Ghiringhelli, F.; Rebe, C.; Hichami, A.; Delmas, D. Immunomodulation and anti-inflammatory roles of polyphenols as anticancer agents. Anticancer Agents Med. Chem. 2012, 12, 852-873. [CrossRef]

244. Yang, Y.; Paik, J.H.; Cho, D.; Cho, J.A.; Kim, C.W. Resveratrol induces the suppression of tumor-derived CD4+CD25+ regulatory T cells. Int. Immunopharmacol. 2008, 8, 542-547. [CrossRef]

245. Brown, V.A.; Patel, K.R.; Viskaduraki, M.; Crowell, J.A.; Perloff, M.; Booth, T.D.; Vasilinin, G.; Sen, A.; Schinas, A.M.; Piccirilli, G.; et al. Repeat dose study of the cancer chemopreventive agent resveratrol in healthy volunteers: Safety, pharmacokinetics, and effect on the insulin-like growth factor axis. Cancer Res. 2010, 70, 9003-9011. [CrossRef] [PubMed]

246. Singh, C.K.; Ndiaye, M.A.; Ahmad, N. Resveratrol and cancer: Challenges for clinical translation. Biochim. Biophys. Acta 2015, 1852, 1178-1185. [CrossRef] [PubMed]

247. Popat, R.; Plesner, T.; Davies, F.; Cook, G.; Cook, M.; Elliott, P.; Jacobson, E.; Gumbleton, T.; Oakervee, H.; Cavenagh, J. A phase 2 study of SRT501 (resveratrol) with bortezomib for patients with relapsed and or refractory multiple myeloma. Br. J. Haematol. 2013, 160, 714-717. [CrossRef]

248. Gupta, S.; Jawanda, M.K.; Arora, V.; Mehta, N.; Yadav, V. Role of lycopene in preventing oral diseases as a nonsurgical aid of treatment. Int. J. Prev. Med. 2015, 6, 70. [CrossRef] [PubMed]

249. Ribeiro, A.S.; Salles, P.R.; da Silva, T.A.; Mesquita, R.A. A Review of the nonsurgical treatment of oral leukoplakia. Int. J. Dent. 2010, 2010, 186018. [CrossRef]

250. Liu, W.; Cui, Y.; Wei, J.; Sun, J.; Zheng, L.; Xie, J. Gap junction-mediated cell-to-cell communication in oral development and oral diseases: A concise review of research progress. Int. J. Oral Sci. 2020, 12, 17. [CrossRef]

251. Bhuvaneswari, V.; Velmurugan, B.; Balasenthil, S.; Ramachandran, C.R.; Nagini, S. Chemopreventive efficacy of lycopene on 7,12-dimethylbenz[a]anthracene-induced hamster buccal pouch carcinogenesis. Fitoterapia 2001, 72, 865-874. [CrossRef]

252. Gustin, D.M.; Rodvold, K.A.; Sosman, J.A.; Diwadkar-Navsariwala, V.; Stacewicz-Sapuntzakis, M.; Viana, M.; Crowell, J.A.; Murray, J.; Tiller, P.; Bowen, P.E. Single-dose pharmacokinetic study of lycopene delivered in a well-defined food-based lycopene delivery system (tomato paste-oil mixture) in healthy adult male subjects. Cancer Epidemiol. Biomark. Prev. 2004, 13, 850-860.

253. Story, E.N.; Kopec, R.E.; Schwartz, S.J.; Harris, G.K. An update on the health effects of tomato lycopene. Annu. Rev. Food Sci. Technol. 2010, 1, 189-210. [CrossRef]

254. Mathews-Roth, M.M. Antitumor activity of beta-carotene, canthaxanthin and phytoene. Oncology 1982, 39, 33-37. [CrossRef]

255. Okuzumi, J.; Takahashi, T.; Yamane, T.; Kitao, Y.; Inagake, M.; Ohya, K.; Nishino, H.; Tanaka, Y. Inhibitory effects of fucoxanthin, a natural carotenoid, on $\mathrm{N}$-ethyl-N'-nitro-N-nitrosoguanidine-induced mouse duodenal carcinogenesis. Cancer Lett. 1993, 68, 159-168. [CrossRef]

256. Grubbs, C.J.; Eto, I.; Juliana, M.M.; Whitaker, L.M. Effect of canthaxanthin on chemically induced mammary carcinogenesis. Oncology 1991, 48, 239-245. [CrossRef] [PubMed]

257. Tanaka, T.; Makita, H.; Ohnishi, M.; Mori, H.; Satoh, K.; Hara, A. Chemoprevention of rat oral carcinogenesis by naturally occurring xanthophylls, astaxanthin and canthaxanthin. Cancer Res. 1995, 55, 4059-4064. [PubMed]

258. Sathasivam, R.; Ki, J.S. A review of the biological activities of microalgal carotenoids and their potential use in healthcare and cosmetic industries. Marine Drugs 2018, 16, 26. [CrossRef]

259. De Lencastre Novaes, L.C.; Jozala, A.F.; Lopes, A.M.; de Carvalho Santos-Ebinuma, V.; Mazzola, P.G.; Pessoa Junior, A. Stability, purification, and applications of bromelain: A review. Biotechnol. Prog. 2016, 32, 5-13. [CrossRef]

260. Rathnavelu, V.; Alitheen, N.B.; Sohila, S.; Kanagesan, S.; Ramesh, R. Potential role of bromelain in clinical and therapeutic applications. Biomed. Rep. 2016, 5, 283-288. [CrossRef]

261. Lee, J.H.; Lee, J.T.; Park, H.R.; Kim, J.B. The potential use of bromelain as a natural oral medicine having anticarcinogenic activities. Food Sci. Nutr. 2019, 7, 1656-1667. [CrossRef]

262. Ley, C.M.; Ni, Q.; Liao, X.; Gao, H.L.; Robinson, N. Bromelain and cardiovascular risk factors in diabetes: An exploratory randomized, placebo controlled, double blind clinical trial. Chin. J. Integr. Med. 2016, 22, 728-737. [CrossRef] 
263. Rodrigo, K.A.; Rawal, Y.; Renner, R.J.; Schwartz, S.J.; Tian, Q.; Larsen, P.E.; Mallery, S.R. Suppression of the tumorigenic phenotype in human oral squamous cell carcinoma cells by an ethanol extract derived from freeze-dried black raspberries. Nutr. Cancer 2006, 54, 58-68. [CrossRef]

264. Chen, K.M.; Sun, Y.W.; Kawasawa, Y.I.; Salzberg, A.C.; Zhu, J.; Gowda, K.; Aliaga, C.; Amin, S.; Atkins, H.; El-Bayoumy, K. Black raspberry inhibits oral tumors in mice treated with the tobacco smoke constituent dibenzo(def,p)chrysene via genetic and epigenetic alterations. Cancer Prev. Res. 2020, 13, 357-366. [CrossRef]

265. El-Bayoumy, K.; Chen, K.M.; Zhang, S.M.; Sun, Y.W.; Amin, S.; Stoner, G.; Guttenplan, J.B. Carcinogenesis of the oral cavity: Environmental causes and potential prevention by black raspberry. Chem. Res. Toxicol. 2017, 30, 126-144. [CrossRef] [PubMed]

266. Warner, B.M.; Casto, B.C.; Knobloch, T.J.; Accurso, B.T.; Weghorst, C.M. Chemoprevention of oral cancer by topical application of black raspberries on high at-risk mucosa. Oral Surg. Oral Med. Oral Pathol. Oral Radiol. 2014, 118, 674-683. [CrossRef] [PubMed]

267. Srinivasan, P.; Suchalatha, S.; Babu, P.V.; Devi, R.S.; Narayan, S.; Sabitha, K.E.; Shyamala Devi, C.S. Chemopreventive and therapeutic modulation of green tea polyphenols on drug metabolizing enzymes in 4-Nitroquinoline 1-oxide induced oral cancer. Chem.-Biol. Interact. 2008, 172, 224-234. [CrossRef] [PubMed]

268. Schwartz, J.L.; Baker, V.; Larios, E.; Chung, F.L. Molecular and cellular effects of green tea on oral cells of smokers: A pilot study. Mol. Nutr. Food Res. 2005, 49, 43-51. [CrossRef] [PubMed]

269. Wang, M.; Jiang, S.; Zhou, L.; Yu, F.; Ding, H.; Li, P.; Zhou, M.; Wang, K. Potential mechanisms of action of curcumin for cancer prevention: Focus on cellular signaling pathways and miRNAs. Int. J. Biological Sci. 2019, 15, 1200-1214. [CrossRef]

270. Tanaka, T.; Makita, H.; Ohnishi, M.; Hirose, Y.; Wang, A.; Mori, H.; Satoh, K.; Hara, A.; Ogawa, H. Chemoprevention of 4-nitroquinoline 1-oxide-induced oral carcinogenesis by dietary curcumin and hesperidin: Comparison with the protective effect of beta-carotene. Cancer Res. 1994, 54, 4653-4659.

271. Livny, O.; Kaplan, I.; Reifen, R.; Polak-Charcon, S.; Madar, Z.; Schwartz, B. Lycopene inhibits proliferation and enhances gap-junction communication of KB-1 human oral tumor cells. J. Nutr. 2002, 132, 3754-3759. [CrossRef]

272. Siddiqui, I.A.; Adhami, V.M.; Bharali, D.J.; Hafeez, B.B.; Asim, M.; Khwaja, S.I.; Ahmad, N.; Cui, H.; Mousa, S.A.; Mukhtar, H. Introducing nanochemoprevention as a novel approach for cancer control: Proof of principle with green tea polyphenol epigallocatechin-3-gallate. Cancer Res. 2009, 69, 1712-1716. [CrossRef]

273. Vadhanam, M.V.; Ravoori, S.; Aqil, F.; Gupta, R.C. Chemoprevention of mammary carcinogenesis by sustained systemic delivery of ellagic acid. Eur. J. Cancer Prev. 2011, 20, 484-491. [CrossRef]

274. Ibrahim, A.; El-Meligy, A.; Fetaih, H.; Dessouki, A.; Stoica, G.; Barhoumi, R. Effect of curcumin and Meriva on the lung metastasis of murine mammary gland adenocarcinoma. In Vivo 2010, 24, 401-408.

275. Aqil, F.; Munagala, R.; Jeyabalan, J.; Vadhanam, M.V. Bioavailability of phytochemicals and its enhancement by drug delivery systems. Cancer Lett. 2013, 334, 133-141. [CrossRef] [PubMed] 